\title{
Exporters in Pakistan and Firms Who Do Not Export: What's the Big Difference?
}

\section{Theresa Chaudhry* and Muhammad Haseeb ${ }^{* *}$}

\begin{abstract}
A variety of stylized facts about exporters have emerged in the new literature on international trade based on firm-level data. These include low levels of export participation among firms; small shares of export sales in firm revenue; larger firms; and higher levels of productivity, skill, and capital intensity among exporters. In this paper, we seek to examine the extent to which these stylized facts fit the experience of firms in Pakistan, using two cross-sections of firm-level datathe Census of Manufacturing Industries (CMI) 2000/01 for Punjab and the World Bank Enterprise Survey dataset (2006/07) for all Pakistan.

We find similar levels of export market participation but very large shares of export sales in firm revenue for those who do, compared to the US sample studied by Bernard, Jensen, Redding, and Schott (2007). We also find, as do many other studies, that exporters exhibit significantly higher total factor productivity (TFP) and are larger in terms of employment than nonexporters. Exporters' TFP was 150 percent higher than non-exporters before we controlled for firm size. Considering the eight largest sectors (which comprise more than 80 percent of the CMI Punjab), with a few exceptions, exporters had higher labor productivity and offered higher compensation to workers, but used more capital per worker and more imported inputs.

The government's recent emphasis on developing the readymade garments sector is well placed: more than half the apparel producers in the CMI Punjab 2000/01 were exporting - and nearly all of their output (93 percent). The capitallabor ratio and use of imported inputs was modest. Exporters were relatively large employers with 400 workers on average and offered significantly higher compensation than nonexporting firms. A greater understanding of firm dynamics could be gained if the CMI were to resume collecting data on firm-level exports (not collected since 2000/01) and if this data were linked across years so that firm performance could be measured over time.
\end{abstract}

\footnotetext{
* Associate Professor of Economics, Lahore School of Economics.

** Research Associate, Centre for Economic Research in Pakistan (CERP).
} 
Keywords: Pakistan, export, firm, sales, revenue, Census of Manufacturing Industries (CMI)

JEL classification: F10, L60.

\section{Introduction}

Following on the obvious successes of the export-led growth of the 'East Asian tigers' and the perceived failures of the earlier inward-looking import-substitution industrialization policies pursued by most developing countries in the decades following independence, developing countries have sought to promote exports as a growth strategy, as both a source of demand and of coveted foreign exchange.

The Washington Consensus, which promoted economic liberalization generally, also recommended freeing trade (through low uniform tariffs and a competitive exchange rate) to improve economic efficiency and eliminate the deadweight losses associated with import restrictions. The argument was that substituting inefficient domestic production with lower-cost supply from abroad and as a source of competition would make surviving domestic producers more efficient. Researchers also documented the experience of East Asia and policymakers sought to emulate their experience. However, these "lessons" can be quite confusing since prominent scholars (for example, Anne Krueger and Dani Rodrik) have disagreed on the extent to which the success of East Asia happened in spite of, or thanks to, government intervention in "picking winners."

Proponents of trade liberalization advocate that there is a relationship between the openness of an economy and the productivity of its firms. The suggested mechanisms through which this works is that the introduction of cheaper imports will (i) reduce the mark-up that firms can charge consumers due to greater competition in the final goods market, and (ii) lower the average cost of production in the sector due to the exit of low-productivity firms that were only able to operate in a protected market (Bernard, Jensen, Redding, \& Schott, 2011). In addition to intra-industry reallocation of resources, within-firm productivity gains have also been documented (Pavcnik, 2002; Trefler, 2004: cited in Bernard et al., 2011).

Productivity is often found to be higher among exporters, which begs the question of the direction of causality. In other words, do firms that are more productive export or does exporting enhance productivity? The 
bulk of the evidence accumulated over the last 15 years (starting with Roberts \& Tybout, 1997) shows that firms that entered export markets were more productive to begin with (also see Bernard \& Jensen, 2004). In other words, there are fundamental differences between firms along dimensions that are difficult to measure, such as entrepreneurial ability. Such features differentiate among firms such that the more productive firms export and the less productive firms do not. This explanation for the positive productivity-exporting relationship also coincides with the Melitz (2003) model, which incorporates the fixed costs of exporting.

Firms have also been found to experience gains in productivity after they began exporting (see Van Biesebroeck, 2006, on Côte d'Ivoire; Mukim, 2011, on India; Aw, Chung, \& Roberts, 2000, on the Republic of Korea; De Loecker, 2007, on Slovenia; Aw, Roberts, \& Xu, 2011, on Taiwan). Some of these gains to productivity post-exporting may be due to "learning by exporting." Bernard et al. (2011) note that more recent evidence indicates that exporting activities can raise returns to the kinds of investments that complement exporting, thus raising the productivity of exporters even further (they also cite Bustos, 2011; Lileeva \& Trefler, 2010; Aw et al., 2011). For example, Aw et al. (2011) find that, in Taiwan, firms that are more productive initially are both more likely to export and invest in research and development, and that these activities cause further increases in productivity.

On the other hand, Gervais (2012) finds that product quality is a better predictor of exporting behavior than firm-level productivity and that idiosyncratic demand also plays a disproportionate role. Easterly, Reshef, and Schwenkenberg (2009), however, downplay the role of import demand and show that technological dispersion (the mass in the far right-tail of the distribution, indicating the existence of a few, highly productive, successful exporters) explains the high concentration of manufacturing exports, which constitute a large share of total trade.

If exporting firms are more productive, can firms be made to become exporters or are firms born exporters? The answer is not necessarily simple. As discussed earlier, to a (likely large) extent, firms selfselect into export markets. That said, other factors, particularly government policy (of either the exporting or importing countries), can also influence the decision to export or the amount exported. This can occur, for instance, through alleviating credit constraints for would-be exporters (Zia, 2008), trade costs both explicit and implicit (Khan \& Kalirajan, 2011), or discouraging firms from entering new markets by imposing stringent 
technical regulations and standards (Chen, Otsuki, \& Wilson, 2006). Zia (2008) finds that, for Pakistan, the loss of subsidized export credit led to a fall in exports, but only among the (credit-constrained) nonpublicly listed firms, which constituted only half the recipients of the subsidized credit. This last observation demonstrates both the promise and pitfalls of governments' export promotion efforts.

\section{The Stylized Facts}

A variety of stylized facts about exporters have emerged in the new literature on international trade based on firm-level data, which have been made available only fairly recently in many cases.

Bernard, Jensen, Redding, and Schott (2007) note that:

1. Export participation tends to be low and the share of exports in sales varies greatly by industry.

2. Firms export a relatively small share of sales.

3. Exporting firms tend to be more productive.

4. Exporters are larger (in terms of employment).

5. Exporters are more skill- and capital-intensive, even in developing countries (Alvarez \& Lopez, 2005: cited in Bernard et al., 2011).

In this paper, we seek to examine the extent to which these stylized facts fit the experience of firms in Pakistan, using two cross-sections of firm-level data - the Census of Manufacturing Industries (CMI) 2000/011 for Punjab and the World Bank Enterprise Survey 2006/07 for all Pakistan.

Looking at the CMI Punjab, eight sectors make up more than 80 percent of the population of firms. These are (in descending order of sector population size): (i) textiles (702 firms), (ii) food manufacturing (323), (iii) apparel (173), (iv) machinery, except electrical (132), (v) fabricated metal products (127), (vi) other chemical products (121), (vii) iron and steel (103), and (viii) electrical machinery apparatus (102). With a few exceptions, exporters in these sectors have higher labor productivity ${ }^{2}$ and offer higher

\footnotetext{
${ }^{1}$ Neither the CMI 2005/06 nor the CMI 2010/11 ask firms about their sales for export, and so we cannot analyze exporters using these datasets. However, we note that the composition of Pakistan's exports has not changed significantly over the period 2000-10, so that an analysis based on the CMI 2000/01 can still provide valid insights (see Table A1 in Annex 1).

${ }^{2}$ Except iron and steel, where the labor productivity of nonexporters is at par.
} 
compensation to their workers, ${ }^{3}$ but also use more capital per worker ${ }^{4}$ and more imported inputs. ${ }^{5}$

\subsection{Export Participation}

According to the CMI 2000/01, about 22 percent of firms are exporters out of 2,136 manufacturing firms in Punjab (Table 1). Using the World Bank Enterprise Survey, for which we have data covering all of Pakistan, we get nearly the same figure, with 23 percent of 1,122 firms reporting some exports (Table 1 ). However, this does not really make Pakistan an outlier; Bernard et al. (2007) calculate a similar proportion of exporters from the 2002 firm census data for the US, at 18 percent of firms.

\footnotetext{
${ }^{3}$ Except iron and steel and electrical machinery, where nonexporters offer slightly higher average compensation to production workers (including contract workers).

${ }^{4}$ Except nonelectrical machinery, where the capital-labor ratio of nonexporters slightly exceeds that of exporters.

${ }^{5}$ Except apparel, where nonexporters use a slightly larger volume of imported inputs.
} 
Table 1: Export participation of manufacturers in Punjab, by sector

\begin{tabular}{|c|c|c|c|c|c|c|}
\hline \multirow[b]{2}{*}{$\begin{array}{l}\text { ISIC } \\
\text { code }\end{array}$} & \multirow[b]{2}{*}{ Industry } & \multicolumn{3}{|c|}{ CMI Punjab 2000/01 } & \multicolumn{2}{|c|}{$\begin{array}{c}\text { Enterprise Survey } \\
2006 / 07\end{array}$} \\
\hline & & $\begin{array}{l}\text { Total } \\
\text { firms }\end{array}$ & $\begin{array}{l}\text { Percentage } \\
\text { exporting }\end{array}$ & $\begin{array}{c}\text { Share of exports in } \\
\text { total sales } \\
\text { (exporters only) }\end{array}$ & $\begin{array}{l}\text { Total } \\
\text { firms }\end{array}$ & $\begin{array}{l}\text { Percentage } \\
\text { exporting }\end{array}$ \\
\hline 311 & $\begin{array}{l}\text { Food manufacturing } \\
\text { (general) }\end{array}$ & 323 & 4.95 & 0.38 & 184 & 6.0 \\
\hline 312 & Food manuf. (other) & 35 & 5.71 & 0.37 & 21 & 14.3 \\
\hline 313 & Beverages & 17 & 11.76 & 0.44 & 10 & 20.0 \\
\hline 314 & Tobacco & 3 & 0.00 & $\mathrm{n} / \mathrm{a}$ & 0 & $\mathrm{n} / \mathrm{a}$ \\
\hline 321 & Textiles & 702 & 22.65 & 0.55 & 206 & 22.8 \\
\hline 322 & Apparel & 173 & 54.34 & 0.93 & 190 & 27.9 \\
\hline 323 & $\begin{array}{l}\text { Leather and leather } \\
\text { products }\end{array}$ & 48 & 45.83 & 0.91 & 74 & 40.5 \\
\hline 324 & Footwear & 9 & 44.44 & 0.57 & & 0.0 \\
\hline 331 & Wood and wood prod. & 18 & 0.00 & $\mathrm{n} / \mathrm{a}$ & 7 & 14.3 \\
\hline 332 & Furniture and fixtures & 13 & 7.69 & 1.00 & 21 & 0.0 \\
\hline 341 & $\begin{array}{l}\text { Paper and paper } \\
\text { products }\end{array}$ & 48 & 10.42 & 0.02 & 11 & 0.0 \\
\hline 342 & $\begin{array}{l}\text { Printing, publishing, } \\
\text { allied industries }\end{array}$ & 33 & 3.03 & 0.10 & 28 & 7.1 \\
\hline 351 & Industrial chemicals & 43 & 6.98 & 0.20 & 26 & 19.2 \\
\hline 352 & Other chemical prod. & 121 & 9.09 & 0.17 & 48 & 35.4 \\
\hline 354 & Petroleum products & 3 & 0.00 & $\mathrm{n} / \mathrm{a}$ & 4 & 25.0 \\
\hline 355 & Rubber products & 23 & 8.70 & 0.51 & 4 & 25.0 \\
\hline 356 & Plastic products & 28 & 3.57 & 0.21 & 37 & 10.8 \\
\hline 361 & $\begin{array}{l}\text { Pottery, china, } \\
\text { earthenware }\end{array}$ & 27 & 7.41 & 0.28 & 3 & 66.7 \\
\hline 362 & Glass and glass prod. & 8 & 25.00 & 0.02 & 9 & 22.2 \\
\hline 369 & $\begin{array}{l}\text { Other nonmetallic } \\
\text { mineral products }\end{array}$ & 33 & 3.03 & 0.02 & 20 & 15.0 \\
\hline 371 & $\begin{array}{l}\text { Iron and steel basic } \\
\text { industries }\end{array}$ & 103 & 1.94 & 0.28 & 39 & 5.1 \\
\hline 372 & $\begin{array}{l}\text { Nonferrous metal basic } \\
\text { industries }\end{array}$ & 10 & 0.00 & $\mathrm{n} / \mathrm{a}$ & 4 & 25.0 \\
\hline 381 & Fabricated metal prod. & 127 & 10.24 & 0.57 & 35 & 25.7 \\
\hline 382 & $\begin{array}{l}\text { Machinery, except } \\
\text { electrical }\end{array}$ & 132 & 9.85 & 0.21 & 14 & 7.1 \\
\hline 383 & $\begin{array}{l}\text { Electrical machinery } \\
\text { apparatus }\end{array}$ & 102 & 13.73 & 0.30 & 46 & 10.9 \\
\hline 384 & Transport equipment & 69 & 2.90 & 0.04 & 10 & 20.0 \\
\hline 385 & Scientific equipment & 48 & 93.75 & 0.98 & 31 & 58.1 \\
\hline \multirow[t]{3}{*}{390} & Other manufacturing & 58 & 81.03 & 0.94 & 66 & 47.0 \\
\hline & Couldn'tidentify & & & & 38 & 13.2 \\
\hline & Total & 2,136 & 21.5 & & 1,122 & 22.99 \\
\hline
\end{tabular}

Source: Authors' calculations based on CMI 2000/01 (full data) and World Bank Enterprise Survey 2006/07 data for Pakistan.

Export participation varies widely by industry in Punjab (Table 1). As we can see from the CMI data, very few food-manufacturing firms 
engage in exports in Punjab (5 percent), in addition to iron and steel (2 percent), transport equipment (3 percent), plastic products (4 percent), industrial chemicals ( 7 percent), pottery ( 7 percent), and furniture and fixtures (8 percent). Industries with a high degree of export participation include footwear (44 percent), apparel (54 percent), leather (46 percent), other manufacturing (81 percent), and scientific equipment (94 percent). Firms in these last three categories export nearly all their output.

The level of export participation among textile firms is average -23 percent of firms in the CMI Punjab - but these export more than half their output. In other sectors as well, the share of exports in total sales is significant for exporting firms despite the low export participation of the sector as a whole. For example, no more than 10 percent of firms export in sectors such as industrial chemicals, plastic products, rubber products, pottery, iron and steel, fabricated metal, and machinery, but the share of exports in total sales for firms that do export ranges from 20 to 50 percent.

Looking at firms' exporting status in the CMI by disaggregated industry codes (Table A2 in Annex 1) yields a slightly clearer picture. While we have already noted that export participation in the foods sector is low, an exception is rice milling at 40 percent of firms. Within textiles, there is significant variation but also a larger share of exporting firms, on average. In industries such as surgical goods, sporting goods and, oddly enough, bone crushing, there are a few firms that do not export.

The data from the Enterprise Survey span a larger geographical area, but are limited to urban areas and about half the number of firms. The export participation numbers are largely consistent with the CMI data for Punjab for industries such as food manufacturing (general), textiles, leather, glass, machinery, and electrical machinery. In other sectors, the World Bank data show export participation to be two or three times greater (with the exception of garments, scientific equipment, and other manufacturing). These differences could be due to the inclusion of the other provinces-particularly Sindh, with its large manufacturing base around Karachi - or the focus on urban areas.

Table 2 gives firms' exporting status by the form of organization and ownership. The upper panel shows there is little variation in the level of export participation by form of ownership (column 1), except for the purely public sector firms, which do not export. Firms (both public and private) with foreign collaboration tend to export, as do private firms that are wholly owned domestically. While firms with foreign collaboration 
participate in exporting activities somewhat more than the average of 21.5 percent, their levels (27.3 and 30.4 percent) are not exceedingly high considering the external partnership. On the other hand, exporting status varies more so with the legal form of organization: only private limited and public limited firms participate in export markets at any significant level. Less than 10 percent of individually owned firms and partnerships participate in export markets (Table 2, lower panel). 
Table 2: Exporting status by ownership and form of organization

\begin{tabular}{|c|c|c|c|c|}
\hline & $\begin{array}{c}(1) \\
\text { Exporters (as \% of } \\
\text { firms in this } \\
\text { category) }\end{array}$ & $\begin{array}{c}(2) \\
\text { Firms in this } \\
\text { category (as \% of } \\
\text { all firms) }\end{array}$ & $\begin{array}{c}\text { (3) } \\
\text { Firms in this } \\
\text { category (as \% of } \\
\text { exporters) }\end{array}$ & $\begin{array}{c}\text { (4) } \\
\text { Number of } \\
\text { firms }\end{array}$ \\
\hline \multicolumn{5}{|l|}{ Form of ownership } \\
\hline $\begin{array}{l}\text { Pakistani, public } \\
\text { sector }\end{array}$ & 0.0 & 0.40 & 0.0 & 9 \\
\hline $\begin{array}{l}\text { Public sector with } \\
\text { foreign collaboration }\end{array}$ & 27.3 & 0.50 & 0.7 & 11 \\
\hline $\begin{array}{l}\text { Pakistani, private- } \\
\text { owned }\end{array}$ & 21.5 & 97.60 & 97.4 & 2,084 \\
\hline $\begin{array}{l}\text { Private sector with } \\
\text { foreign collaboration }\end{array}$ & 30.4 & 1.10 & 1.5 & 23 \\
\hline Foreign-controlled & 22.2 & 0.40 & 0.4 & 9 \\
\hline \multicolumn{5}{|l|}{ Form of organization } \\
\hline $\begin{array}{l}\text { Individual } \\
\text { ownership }\end{array}$ & 7.8 & 21.00 & 7.6 & 449 \\
\hline Partnership & 8.3 & 23.20 & 8.9 & 496 \\
\hline Private limited & 25.4 & 39.90 & 47.2 & 853 \\
\hline Public limited & 51.9 & 15.10 & 36.3 & 322 \\
\hline Other & 0.0 & 0.75 & 0.0 & 16 \\
\hline Total & 21.5 & & 100.0 & 2,136 \\
\hline
\end{tabular}

Source: Authors' calculations based on CMI 2000/01 (full data). The "other" category includes cooperative societies, federal ownership, provincial government establishments, and other unspecified ownership structures.

\subsection{Share of Exports in Firm Revenues}

In the case of US firms, Bernard et al. (2007) find that only around 14 percent of sales are exports, ranging from 7 to 21 percent. In the CMI Punjab, there is significantly greater variation: among exporters, the average percentage of sales for export is 51 percent, with sector averages ranging from 2 to 98 percent. The World Bank Enterprise Survey records the average share of exports as 67 percent, although the information on the share of export sales was asked as a direct question rather than calculated using the firms' administrative data.

Nearly half the 460 exporters in the CMI Punjab reported that at least 90 percent of their sales were destined for foreign markets; 34 percent said they exported exclusively, i.e., all sales were exports (see Table 3). Just over half the exporters interviewed in the Enterprise Survey responded similarly. As we can see, exporters in Pakistan rely very heavily on exports and many do not have much domestic presence at all. Typically, we tend to think that firms that diversify into foreign markets are protected informally 
against domestic demand slumps so long as their export markets are not hit equally by the same demand shocks. However, when exporters have such a limited domestic presence, they may be left very vulnerable to exchange rate movements and other external shocks.

Table 3: Distribution of the share of exports in sales

\begin{tabular}{lcc}
\hline Export share in sales & $\begin{array}{c}\text { Share of exporters } \\
\text { (CMI Punjab) }\end{array}$ & $\begin{array}{c}\text { Share of exporters } \\
\text { (Enterprise Survey) }\end{array}$ \\
\hline$<0.05$ & 0.12 & 0.05 \\
$0.05-0.15$ & 0.07 & 0.16 \\
$0.15-0.3$ & 0.06 & 0.07 \\
$0.3-0.5$ & 0.05 & 0.08 \\
$0.5-0.7$ & 0.09 & 0.04 \\
$0.7-0.9$ & 0.13 & 0.07 \\
$>0.9$ & 0.48 & 0.52 \\
\hline
\end{tabular}

Source: Authors' calculations based on CMI 2000/01 (full data) and World Bank Enterprise Survey 2006/07 data for Pakistan.

\section{Productivity of Exporters}

In this section, we look at a variety of productivity measures, including firm-level total factor productivity (following the techniques of Hsieh \& Klenow, 2009) and labor productivity, comparing the performance of exporters to non-exporters along these dimensions.

\subsection{Total Factor Productivity}

We find, following the techniques used by Hsieh and Klenow (2009) for measuring total factor productivity (TFP), that exporters are more productive than nonexporters. ${ }^{6}$

Based on a Cobb-Douglas firm-level production function,

$$
Y_{s i}=A_{s i} K_{s i}^{\alpha_{s}} L_{s i}^{1-\alpha_{s}}
$$

Where $K_{s i}$ and $L_{s i}$ represent capital and labor respectively, and $A_{s i}$ represents the firm's individual output-based TFP measure, referred to as TFPQ for firm $i$ in sector $s$. TFPQ is written as:

\footnotetext{
${ }^{6}$ See Annex 2 or Hsieh and Klenow (2009) for more details on how these measures were derived.
} 


$$
T F P Q_{s i}=A_{s i}=\frac{Y_{s i}}{K_{s i}^{\alpha_{s}} L_{s i}^{1-\alpha_{s}}}
$$

Naturally, different firms will have different values of $A_{s i}$ because all firms, depending on the characteristics of their owners and managers, location, and even luck, will differ in levels of entrepreneurial ability, organizational capital, and access to customers, among others. As we can see in both panels of Figure 1, the mean TFPQ is higher for exporters than for nonexporters in both the CMI Punjab and the World Bank Enterprise Survey samples, although the difference between the two groups of firms is greater in the former. There is also greater spread in the distribution of TFPQ and a long tail on the left-hand side of the distribution for nonexporters in the CMI Punjab sample, indicating a high level of dispersion and the survival of low-productivity firms.

\section{Figure 1: Distributions of TFPQ for exporters vs. nonexporters}

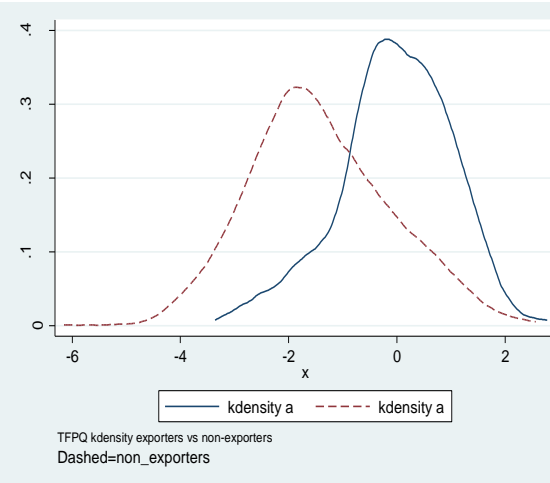

Panel A: CMI Punjab 2000/01

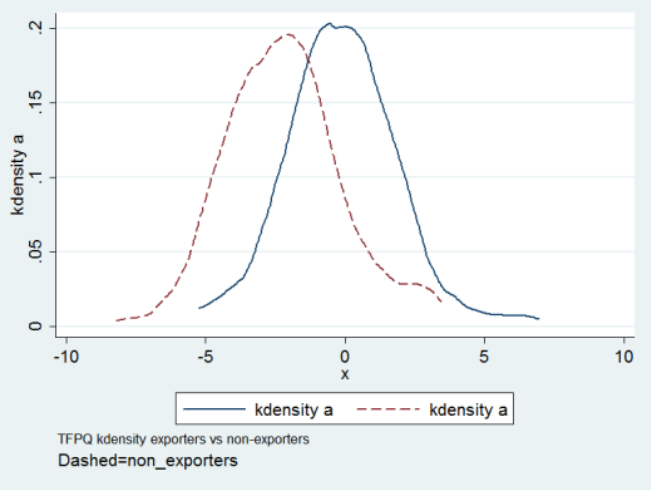

Panel B: Enterprise Survey 2006/07

Source: Authors' calculations.

An alternative productivity measure that can be used to measure distortions in the economy is the revenue-based TFP measure, or $P_{s i} A_{s i}$, referred to as TFPR for firm $i$ in sector $s$ is defined from the production function as:

$$
T F P R_{s i}=P_{s i} A_{s i}=\frac{P_{s i} Y_{s i}}{K_{s i}^{a_{i}} L_{s i}^{1-\alpha_{s}}}
$$

The idea underlying the revenue-based TFPR measure of productivity is that firms that are more efficient (with higher $A_{s i}$ or $T F P Q$ ) 
should optimally produce a higher level of output but, as a result, will sell their product variety at a relatively low price (Hsieh \& Klenow, 2009). Assuming there are no distortions in the economy - so that some firms are not relatively disadvantaged compared to others - with regard to policies such as regulation or credit, then more resources will be allocated toward efficient producers such that the marginal products of capital and labor are equated across firms. In this way, TFPR should equalize across firms regardless of the distribution of $A_{s i}$ (or TFPQ), as long as the economy is relatively undistorted.

Dispersion in TFPR (Figure 2), therefore, indicates the presence of distortions in the economy: firms with a high (low) TFPR are those that should be allocated more (fewer) resources-capital and labor-and should be bigger (smaller) than their current operations. As expected, TFPR displays less dispersion than TFPQ and the gap between exporters and nonexporters is narrowed but not eliminated.

Figure 2: Distributions of TFPR for exporters vs. nonexporters

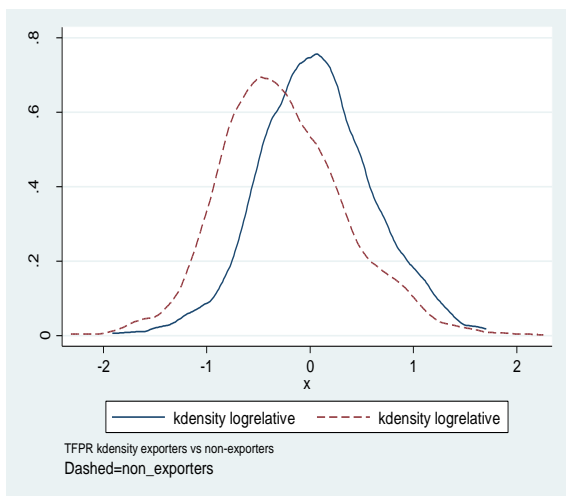

Panel A: CMI Punjab 2000/01

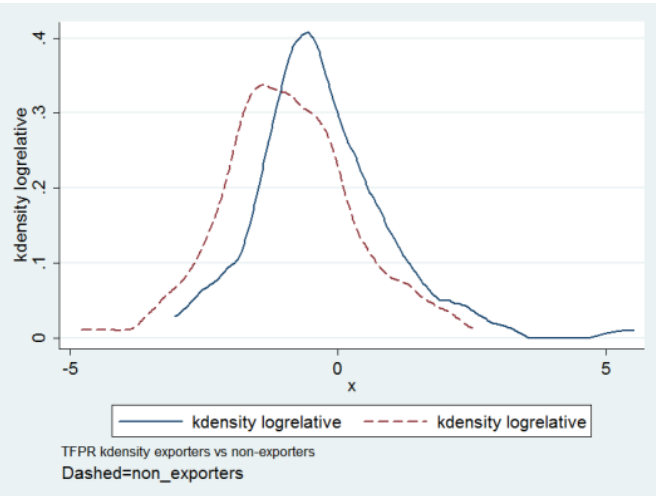

Panel B: Enterprise Survey 2006/07

Source: Authors' calculations.

In this context, firms in the right-tail of the distribution (with a high TFPR) have a high marginal productivity because they are somehow constrained, unable to obtain enough resources to grow to the extent that marginal productivity would come down to the sector average. The World Bank sample's TFPR distribution exhibits a long right-tail. On the other hand, the TFPR distribution of nonexporters in both samples has a long lefttail. These firms are those that have low marginal productivities compared to the industry average and are too large (have too many resources). 
Another view of the differences in TFP distribution according to exporting status emerges when we examine the dispersion statistics calculated in Table 4 . The output-based TFPQ distribution for exporters has a smaller standard deviation and lower ratios of the 75th to the 25th percentile and of the 90th to the 10th percentile compared to nonexporters. The same pattern applies to the revenue-based TFPR measure where dispersion represents the misallocation of productive resources. 
Table 4: Dispersion of TFP, CMI Punjab 2000/01

\begin{tabular}{lccc|ccc}
\hline & \multicolumn{3}{c|}{ TFPQ } & \multicolumn{3}{c}{ TFPR } \\
\cline { 2 - 7 } & SD & $\begin{array}{c}\text { Ratio 75-25 } \\
\text { percentile }\end{array}$ & $\begin{array}{c}\text { Ratio 90-10 } \\
\text { percentile }\end{array}$ & SD & $\begin{array}{c}\text { Ratio 75-25 } \\
\text { percentile }\end{array}$ & $\begin{array}{c}\text { Ratio 90-10 } \\
\text { percentile }\end{array}$ \\
\hline Nonexporters & 1.46 & 1.78 & 1.67 & 0.66 & 0.92 & 3.92 \\
Exporters & 1.00 & 1.31 & 1.33 & 0.54 & 0.69 & 2.49 \\
\hline
\end{tabular}

Source: Authors' calculations.

A potential concern is that other factors, such as firm size, may differ systematically for exporters and account for the differences in TFP seen in Figures 1 and 2. To address this, we regress the TFP of firms (relative to the sector mean) on exporting status in addition to a number of observable firm-level characteristics. It is important to note that these regressions are not intended to establish causality, but simply correlation. The regression equations are:

$$
\begin{aligned}
& \log T F P Q_{s i}-\log \overline{T F P Q_{s}}=\beta_{0}+\sum_{j} \beta_{j} X_{j s i}+\varepsilon_{s i} \\
& \log T F P R_{s i}-\log \overline{T F P R_{s}}=\beta_{0}+\sum_{j} \beta_{j} X_{j s i}+\varepsilon_{s i}
\end{aligned}
$$

The dependent variable is the log difference of firm-level TFP (for firm $i$ in sector $s$ ) from the average TFP for sector $s$, for TFPQ and TFPR, respectively. $X_{j}$ represents dummy variables for the firm-level characteristics considered (exporting status, firm size, ownership, and location). ${ }^{7}$

Until we add controls for firm size, exporters have a 29 percenthigher TFPR and 150 percent-higher TFPQ compared to nonexporters even after controlling for firm-level characteristics such as geographical location and ownership status (Table 5a). Controlling for firm size causes the coefficient of exporting status to fall appreciably in magnitude for both the TFPQ and TFPR regressions and to lose statistical significance in the regression on TFPR. This result should not be surprising since exporters tend to be larger (see Figures $4 \mathrm{a}$ and $4 \mathrm{~b}$ ).

Similar to the results here, Hsieh and Klenow (2009) find exporters' TFPQ and TFPR to be around 50 percent and 6 percent higher, respectively,

\footnotetext{
${ }^{7}$ The districts in each region are: northern Punjab (Rawalpindi, Attock, Jhelum, and Chakwal); southern Punjab (Bahawalpur, Bahawalnagar, Rahimyar Khan, Multan, Khanewal, Lodhran, and Vehari); western Punjab (Dera Ghazi Khan, Layyah, Muzaffargarh, Bhakkar, Khushab, Rajanpur, and Mianwali); central Punjab (Faisalabad, Jhang, Toba Tek Singh, Nankana Sahib, Gujranwala, Gujrat, Mandi Bahauddin, Hafizabad, Sialkot, Narowal, Sheikhupura, Kasur, Okara, Sahiwal, Pakpattan, Sargodha, and Lahore).
} 
for US firms. On the other hand, they find Chinese exporters' TFPQ to be 46 percent higher while their TFPR is 14 percent lower. We cannot say, however, that exporting status is a causal factor for TFP. It could be that exporting induces firms to grow larger or that large firms are able to become exporters, or that a third factor (such as entrepreneurship or productivity) is related both to firm size and exporting status. The literature already shows that firms that export tend to have a higher productivity even before exporting compared to firms who do not.

Table 5a: Regressions of firm-level TFP on firm characteristics, all firms, CMI 2000/01

\begin{tabular}{lcccc}
\hline & $\begin{array}{c}(\mathbf{1}) \\
\text { Log relative } \\
\text { TFPQ }\end{array}$ & $\begin{array}{c}\text { Log relative } \\
\text { TFPQ }\end{array}$ & $\begin{array}{c}(\mathbf{( 3 )} \\
\text { Log relative } \\
\text { TFPR }\end{array}$ & $\begin{array}{c}(\mathbf{4}) \\
\text { Log relative } \\
\text { TFPR }\end{array}$ \\
\hline Exporter (dummy) & $1.522^{* * *}$ & $0.100^{*}$ & $0.294^{* * *}$ & 0.0213 \\
& $(26.53)$ & $(1.752)$ & $(10.46)$ & $(0.584)$ \\
Foreign-controlled & $2.808^{* * *}$ & $1.334^{* * *}$ & 0.232 & -0.0482 \\
(dummy) & $(5.052)$ & $(3.269)$ & $(0.851)$ & $(-0.185)$ \\
Foreign collaboration & $1.932^{* * *}$ & $0.803^{* * *}$ & $0.425^{* * *}$ & $0.202^{*}$ \\
(dummy) & $(8.326)$ & $(4.666)$ & $(3.732)$ & $(1.836)$ \\
Northern Punjab & 0.0578 & 0.143 & $0.123^{* *}$ & $0.148^{* *}$ \\
& $(0.452)$ & $(1.524)$ & $(1.963)$ & $(2.484)$ \\
Southern Punjab & $-0.199^{* *}$ & $0.116^{*}$ & 0.0575 & $0.148^{* * *}$ \\
& $(-2.130)$ & $(1.676)$ & $(1.255)$ & $(3.348)$ \\
Western Punjab & $0.713^{* * *}$ & $0.252^{* *}$ & 0.0867 & -0.00230 \\
& $(4.835)$ & $(2.320)$ & $(1.197)$ & $(-0.0332)$ \\
First quartile (smallest & & $-3.063^{* * *}$ & & $-0.726^{* * *}$ \\
firms) & & $(-37.60)$ & & $(-13.97)$ \\
Second quartile & $-2.023^{* * *}$ & & $-0.331^{* * *}$ \\
& & $(-28.99)$ & & $(-7.424)$ \\
Third quartile & $-1.329^{* * *}$ & & $-0.213^{* * *}$ \\
& & $(-20.72)$ & & $(-5.208)$ \\
\hline Observations & & 1,793 & 1,793 & 1,793 \\
Adjusted R-squared & 1,793 & 0.636 & 0.062 & 0.154 \\
\hline
\end{tabular}

Note: t-statistics in parentheses; ${ }^{* * *} \mathrm{p}<0.01,{ }^{* *} \mathrm{p}<0.05,{ }^{*} \mathrm{p}<0.1$.

In Table 5b, we limit the analysis to exporting firms to see how exporting intensity is related to TFP. A 1 percent increase in exports is associated with a 23 percent-higher TFPQ and a 9 percent-higher TFPR (columns 1 and 3). A one-percentage point change in exports/sales ratio is associated with a 1.17 percent increase in TFPQ and a 0.669 percent increase in TFPR (columns 2 and 4). 
Table 5b: Regressions of firm-level TFP on firm characteristics, exporters only, CMI 2000/01

\begin{tabular}{lcccc}
\hline & $\begin{array}{c}(\mathbf{1}) \\
\text { Log relative } \\
\text { TFPQ }\end{array}$ & $\begin{array}{c}(\mathbf{2}) \\
\text { Log relative } \\
\text { TFPQ }\end{array}$ & $\begin{array}{c}(\mathbf{3}) \\
\text { Log relative } \\
\text { TFPR }\end{array}$ & $\begin{array}{c}(\mathbf{4}) \\
\text { Log relative } \\
\text { TFPR }\end{array}$ \\
\hline Log (exports) & $0.234^{* * *}$ & & $0.0935^{* * *}$ & \\
& $(11.10)$ & & $(6.643)$ & \\
Ratio exports/sales & & $1.171^{* * *}$ & & $0.669^{* * *}$ \\
Foreign-controlled & & $(10.23)$ & & $(9.374)$ \\
(dummy) & 1.230 & 1.572 & -0.161 & 0.0877 \\
Foreign collaboration & $(0.982)$ & $(1.230)$ & $(-0.193)$ & $(0.110)$ \\
(dummy) & 0.257 & 0.311 & 0.116 & 0.224 \\
Northern Punjab & $(0.600)$ & $(0.713)$ & $(0.408)$ & $(0.824)$ \\
& -0.201 & -0.126 & -0.214 & -0.118 \\
Southern Punjab & $(-0.941)$ & $(-0.575)$ & $(-1.500)$ & $(-0.867)$ \\
& -0.0434 & -0.0221 & 0.0551 & 0.0951 \\
Western Punjab & $(-0.309)$ & $(-0.154)$ & $(0.588)$ & $(1.063)$ \\
& 0.107 & $0.287^{*}$ & -0.0781 & 0.0138 \\
First quartile (smallest & $(0.668)$ & $(1.758)$ & $(-0.732)$ & $(0.135)$ \\
firms) & $-1.274^{* * *}$ & $-2.666^{* * *}$ & 0.0841 & $-0.525^{* *}$ \\
Second quartile & $(-3.150)$ & $(-6.643)$ & $(0.312)$ & $(-2.100)$ \\
& $-1.033^{* * *}$ & $-2.029^{* * *}$ & -0.0968 & $-0.520^{* * *}$ \\
Third quartile & $(-3.961)$ & $(-7.976)$ & $(-0.557)$ & $(-3.276)$ \\
& $-0.792^{* * *}$ & $-1.356^{* * *}$ & $-0.190^{* *}$ & $-0.418^{* * *}$ \\
& $(-6.140)$ & $(-11.16)$ & $(-2.209)$ & $(-5.519)$ \\
\hline Observations & 398 & 398 & 398 & 398 \\
Adjusted R-squared & 0.452 & 0.432 & 0.153 & 0.231 \\
\hline
\end{tabular}

Note: t-statistics in parentheses; ${ }^{* * *} \mathrm{p}<0.01,{ }^{* *} \mathrm{p}<0.05,{ }^{*} \mathrm{p}<0.1$.

\section{Labor Productivity}

This section compares the mean labor productivity of exporters to that of nonexporters by industry. ${ }^{8}$ Mean labor productivity is higher among exporters in 13 of the 19 sectors in the CMI, including seven of the eight largest sectors that comprise more than 80 percent of manufacturing firms in Punjab ${ }^{9}$ (Figure 3a and Figure A1 in Annex 4). These differences exhibit large margins in food manufacturing (3.8 times), paper products

\footnotetext{
${ }^{8}$ Following the OECD methodology, labor productivity is calculated as the ratio of value-added to employment. We have taken the number of production workers (including contract workers) as the number of workers.

${ }^{9}$ Of the eight largest sectors (in terms of the number of firms), only in iron and steel was the labor productivity of nonexporters at par with that of exporters.
} 
(3.4 times), other chemicals (2.7 times), leather products (three times), textiles (nearly 2.5 times), apparel (2.9 times), nonelectrical machinery (2.6 times), fabricated metal products (2.5 times), and pottery (1.8 times). The labor productivity of nonexporters is exceeded by that of exporters by a large margin only in the minor sectors of nonmetallic minerals and scientific equipment.

Figure 3a: Average labor productivity, by sector and exporting status, CMI 2000/01

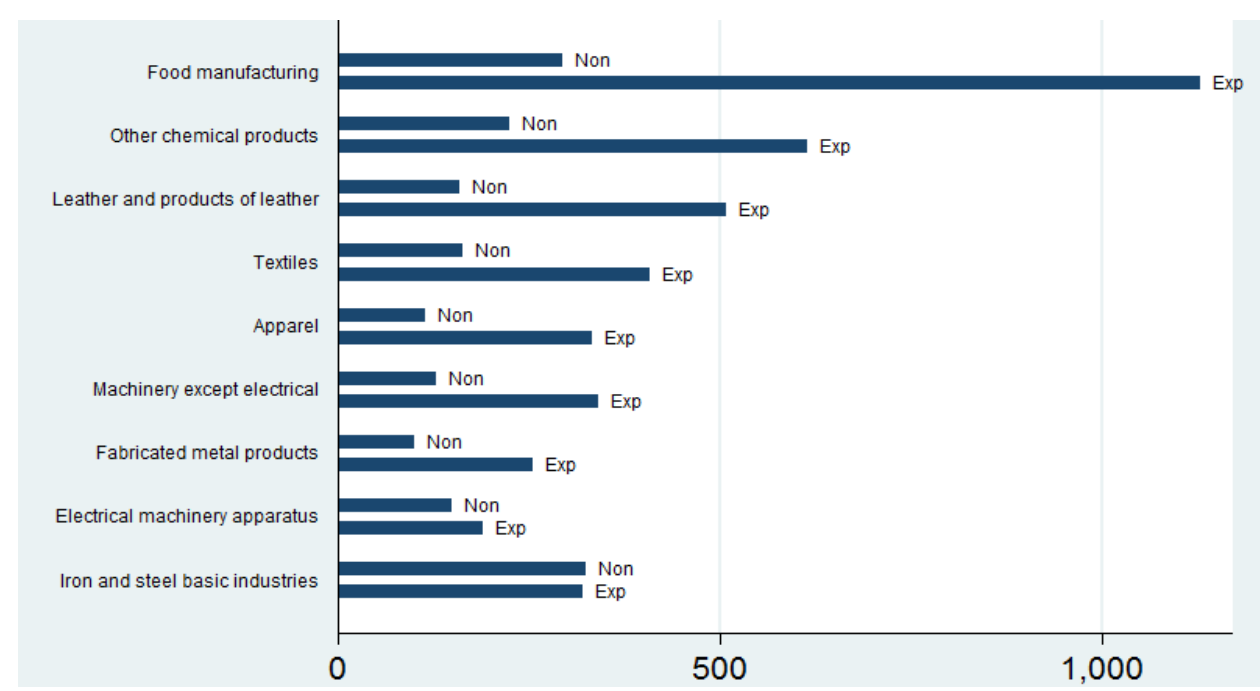

Source: Authors' calculations based on CMI 2000/01 (trimmed data).

Using the World Bank Enterprise Survey's 2006/07 smaller dataset for all Pakistan, we consider a smaller group of sectors to ensure a sufficient number of firms per sector (Figure $3 b$ ). The average labor productivity of exporters is two to three times that of nonexporters for food manufacturing, textiles, other chemicals, other manufacturing, and garments, and by a smaller margin for leather goods. Only in electrical machinery is the pattern reversed. 
Figure 3b: Average labor productivity, by sector and exporting status, Enterprise Survey 2006/07

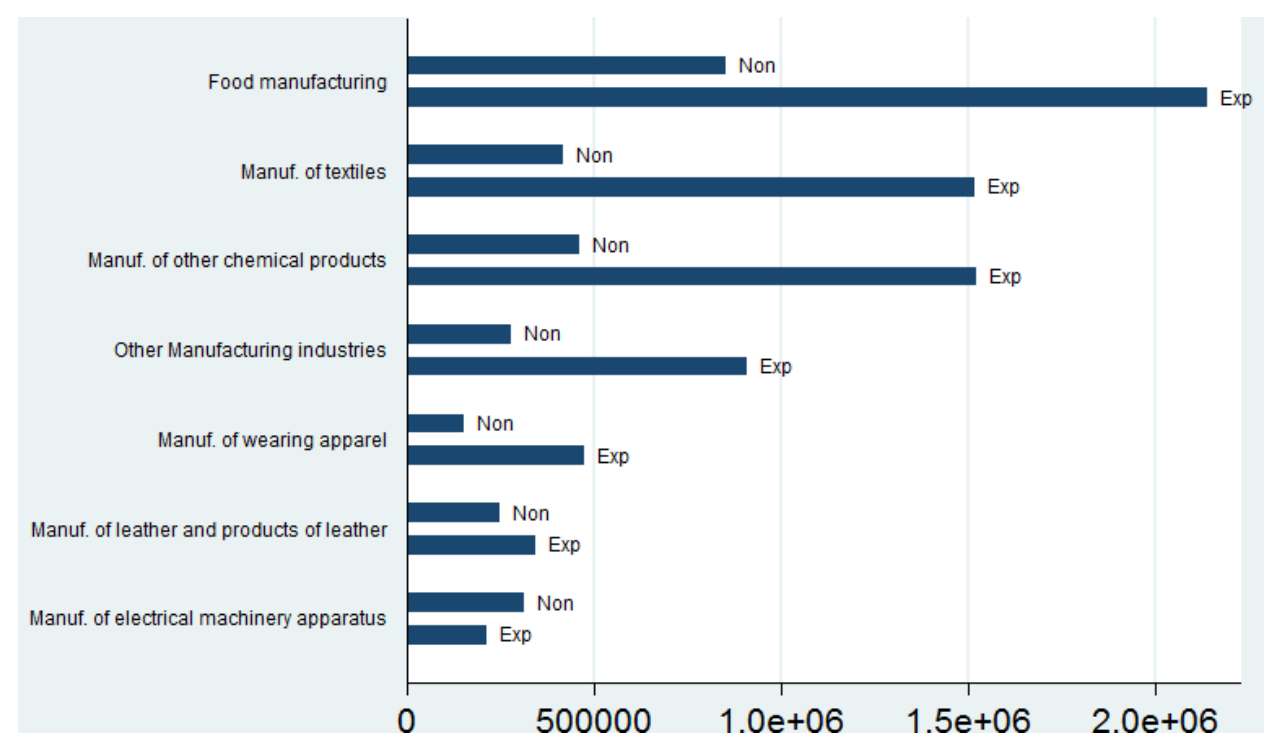

Source: Authors' calculations based on World Bank Enterprise Survey 2006/07.

\section{Relative Size of Exporters}

In the CMI Punjab 2000/01, exporting firms have higher average employment than nonexporting firms in 15 out of 19 sectors (Figure $4 \mathrm{a}$ and Figure A2 in Annex 4). In some sectors, the average size of exporters dwarfs that of nonexporters. For example, in textiles, exporters are (in terms of employment) around four times the size of nonexporters on average; in garments, exporters are around eight times the size of nonexporters. 
Figure 4a: Average employment, by sector and exporting status, CMI 2000/01

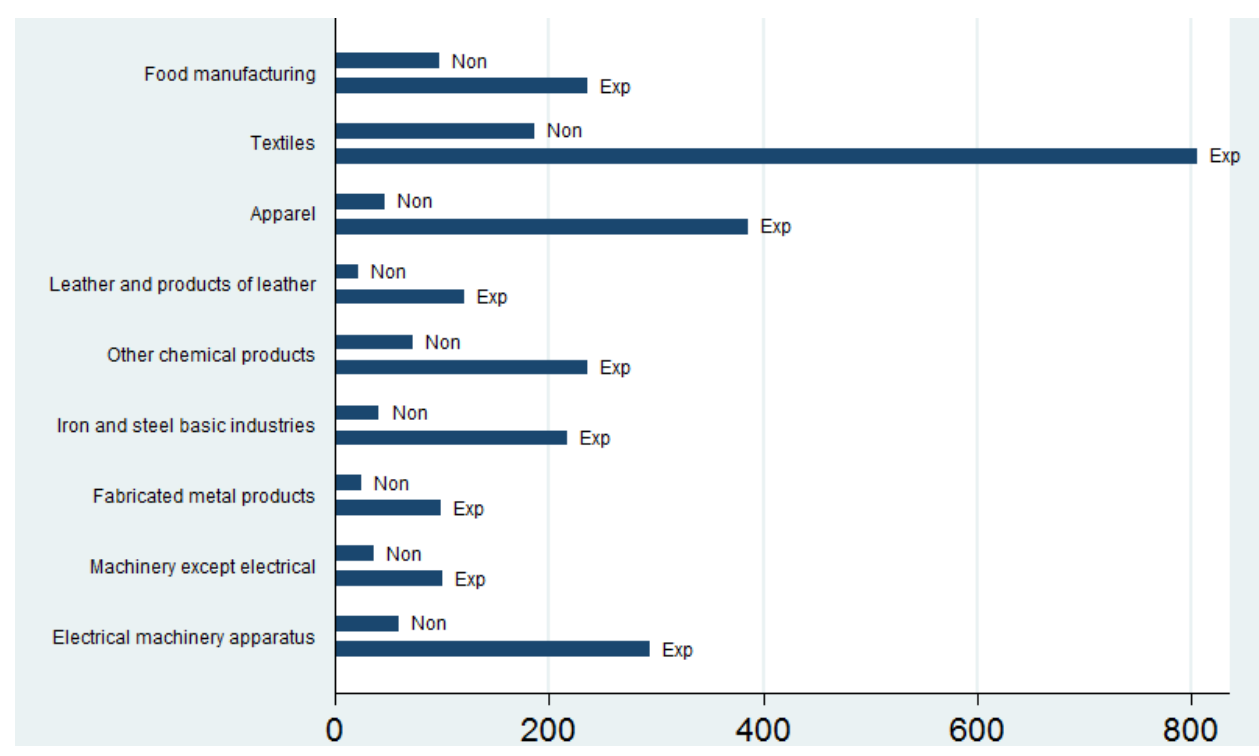

Source: Authors' calculations based on CMI 2000/01 (trimmed data).

The scale of exporters is also much larger in several other sectors, including paper products (ten times), leather products (five times), iron and steel (five times), electrical machinery (almost five times), pottery (4.5 times), fabricated metal products (four times), other manufacturing (four times), industrial chemicals (three times), other chemicals (three times), nonelectrical machinery (2.5 times), food manufacturing (nearly 2.5 times), rubber products (twice), and plastic products (twice). Only in the minor industries of transport equipment, scientific equipment, and nonmetallic mineral products were nonexporting firms larger. The average size of exporters dwarfs that of nonexporters in all seven sectors considered from the Enterprise Survey 2006/07 for all Pakistan (Figure 4b). 
Figure 4b: Average employment, by sector and exporting status, Enterprise Survey 2006/07

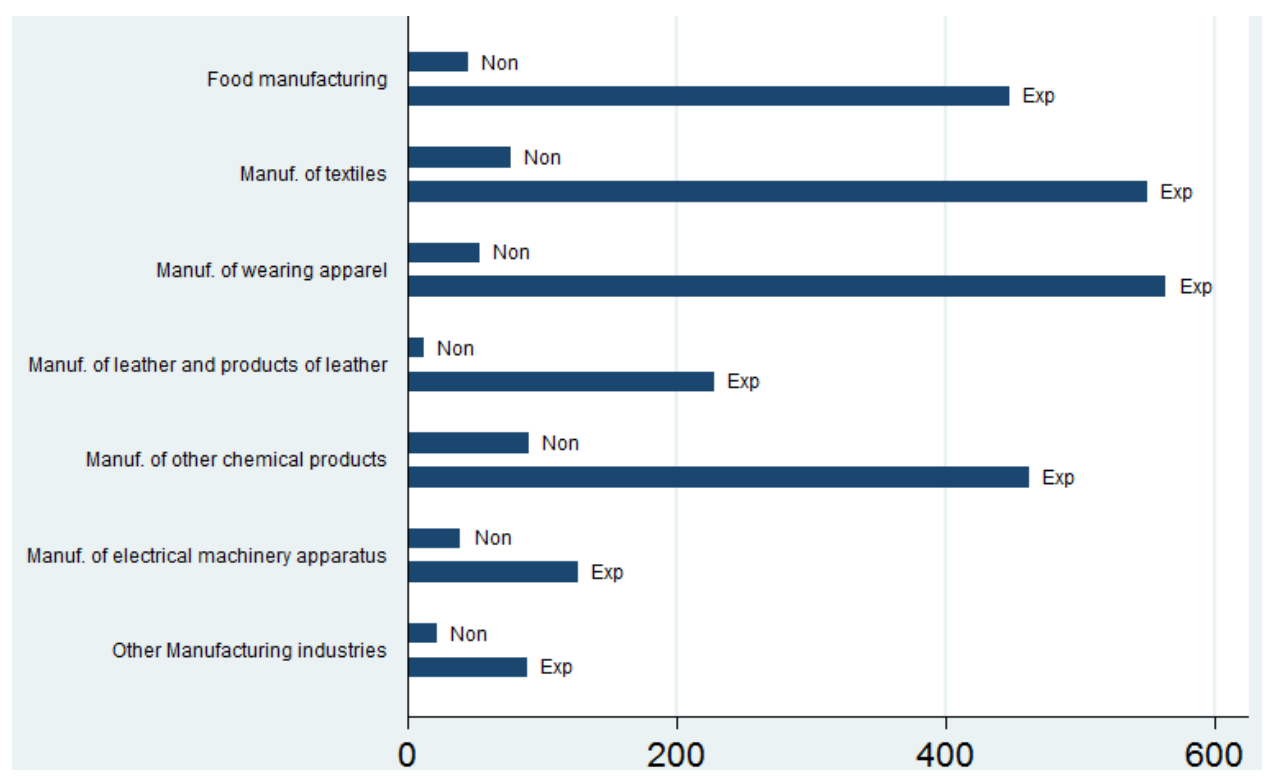

Source: Authors' calculations based on Enterprise Survey 2006/07.

\section{Skill and Capital Intensity of Exporters}

While we do not have information on the skill level of workers, some significant differences emerge between exporters and nonexporters' average compensation for production and contract workers. At least part of these differences are likely attributable to skill differences, even if capital intensity differs.

The CMI Punjab dataset for 2000/01 yields dramatic differences, with workers in exporting firms being paid twice as much as those in nonexporting firms in some sectors, such as food manufacturing, leather products, paper products, and pottery (Figure 5a and Figure A3 in Annex 4). Considerable, if less extreme, differences are evident in the compensation paid to workers in textiles, garments, nonelectrical machinery, fabricated metal products, printing, and other chemicals. Compensation was roughly similar for exporters and nonexporters in industrial chemicals and other manufacturing, while nonexporters offered somewhat better compensation in the rubber, plastic, nonmetallic mineral products, iron and steel, electrical machinery, transport equipment, and scientific equipment sectors. 


\section{Figure 5a: Average compensation for production (including contract) workers, by sector and exporting status, CMI 2000/01}

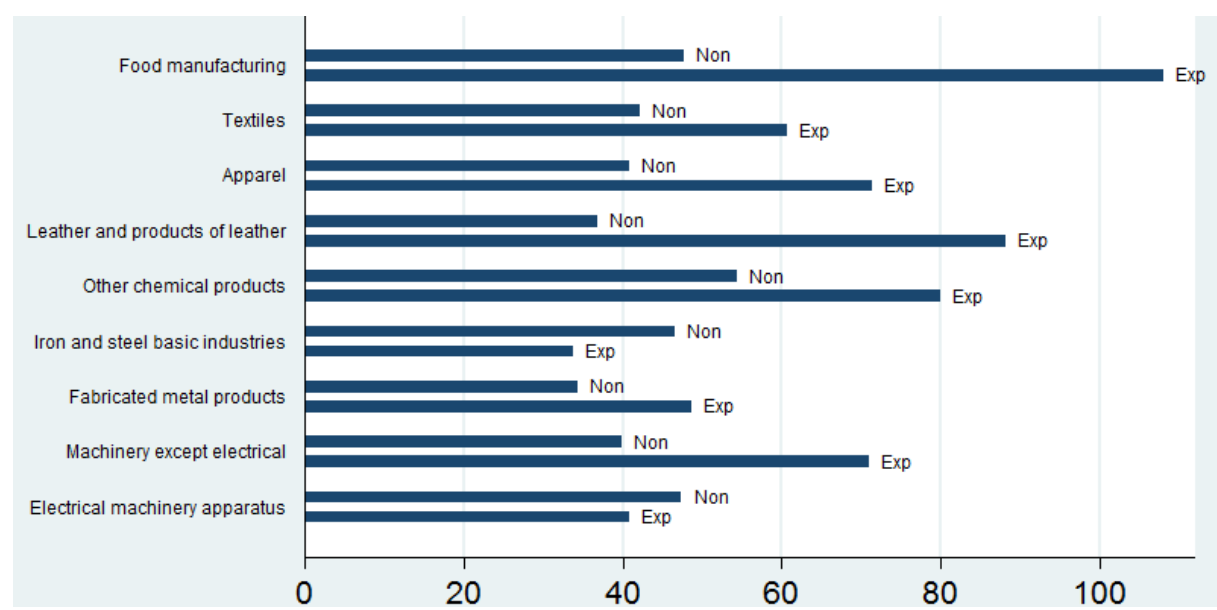

Source: Authors' calculations based on CMI 2000/01 (trimmed data).

Based on the Enterprise Survey 2006/07 for all Pakistan, workers in exporting firms were far better paid in food manufacturing, garments, and other chemicals; somewhat better paid in textiles and electrical machinery; and lower paid on average in other manufacturing (Figure 5b). The average pay was about even in leather goods production.

\section{Figure 5b: Average compensation for production (including contract)} workers, by sector and exporting status, Enterprise Survey 2006/07

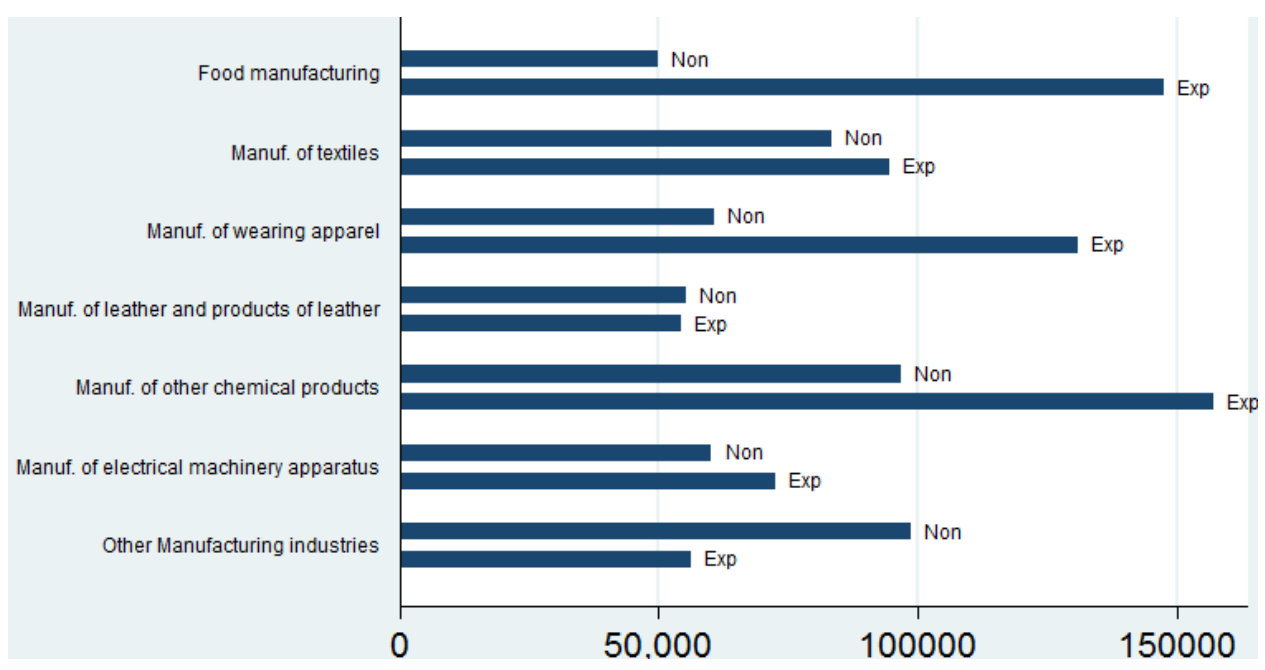

Source: Authors' calculations based on World Bank Enterprise Survey 2006/07. 
There are also very large differences in the capital-labor ratio between exporters and nonexporters in some industries surveyed in the CMI Punjab (Figure 6a and Figure A4 in Annex 4). In food manufacturing, textiles, paper products, leather products, and printing, the capital-labor ratio among exporters is at least twice that of nonexporters. For a few industries, the inequality moves in the other direction, so that nonexporters' capital per worker greatly exceeds that of exporters (in nonmetallic mineral products and plastic products). The differences in the capital-labor ratio are more modest in other sectors, with that of exporters exceeding nonexporters in garments, other chemicals, transport equipment, fabricated metal, iron and steel, and electrical machinery (see also Table 6).

Figure 6a: Capital-labor ratio, by sector and exporting status, CMI 2000/01

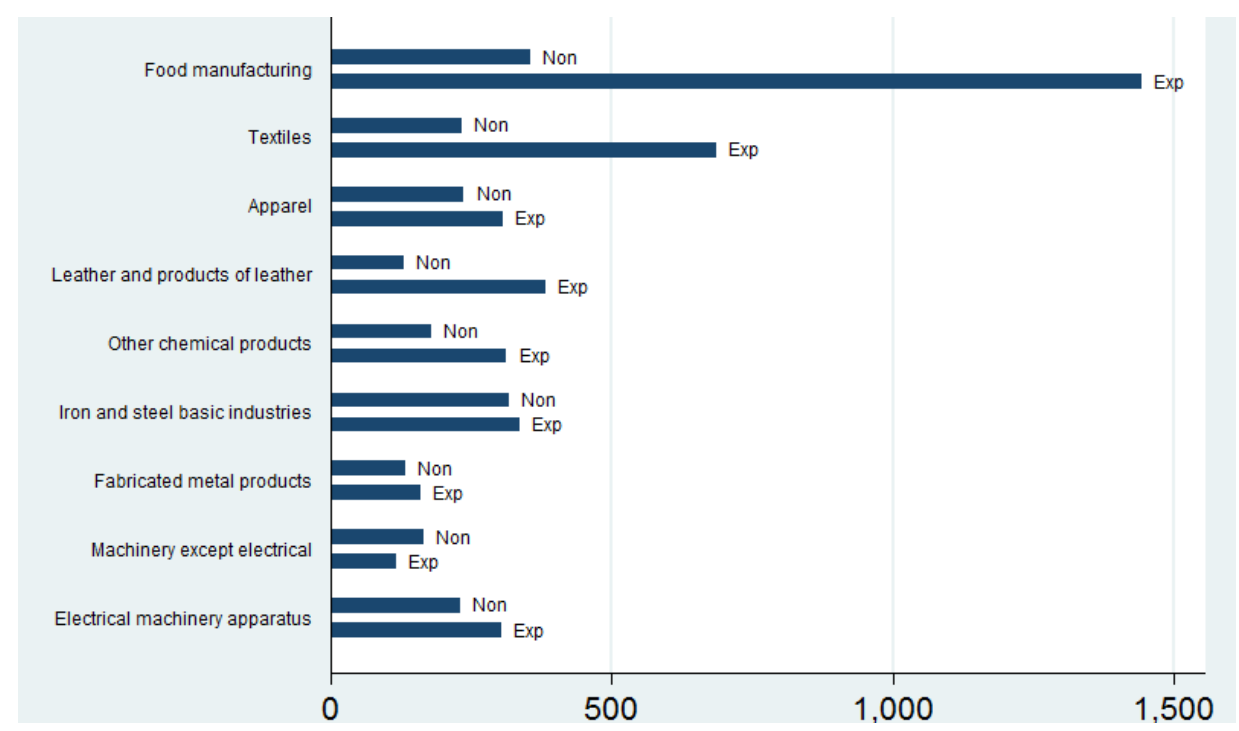

Source: Authors' calculations based on CMI 2000/01 (trimmed data). 
Table 6: Capital purchases of exporting and nonexporting firms, by
sector

\begin{tabular}{|c|c|c|c|c|}
\hline \multirow[b]{2}{*}{ Industry } & \multicolumn{2}{|c|}{$\begin{array}{c}\text { Percentage that imported } \\
\text { machinery }\end{array}$} & \multicolumn{2}{|c|}{$\begin{array}{l}\text { Percentage that bought local } \\
\text { machinery }\end{array}$} \\
\hline & Nonexporters & Exporters & Nonexporters & Exporters \\
\hline Food manufacturing & 2.6 & 6.3 & 21.9 & 62.5 \\
\hline Textiles & 4.5 & 30.1 & 25.5 & 71.3 \\
\hline Apparel & 1.4 & 4.7 & 19.2 & 53.5 \\
\hline $\begin{array}{l}\text { Leather and products } \\
\text { of leather }\end{array}$ & 4.5 & 5.9 & 9.1 & 35.3 \\
\hline Paper and paper prod. & 2.6 & 50.0 & 15.4 & 75.0 \\
\hline $\begin{array}{l}\text { Printing, publishing } \\
\text { and allied industries }\end{array}$ & 6.5 & & 6.5 & 100.0 \\
\hline Industrial chemicals & 5.1 & 33.3 & 30.8 & 100.0 \\
\hline Other chemical prod. & & 11.1 & 35.4 & 77.8 \\
\hline Rubber products & & 50.0 & 15.8 & 50.0 \\
\hline Plastic products & 7.7 & & 34.6 & 100.0 \\
\hline $\begin{array}{l}\text { Pottery, china, } \\
\text { earthenware }\end{array}$ & & & 8.0 & 50.0 \\
\hline $\begin{array}{l}\text { Other nonmetallic } \\
\text { mineral products }\end{array}$ & & & 10.0 & 100.0 \\
\hline $\begin{array}{l}\text { Iron and steel basic } \\
\text { industries }\end{array}$ & 1.1 & & 13.3 & 50.0 \\
\hline Fabricated metal prod. & & 9.1 & 8.6 & 9.1 \\
\hline $\begin{array}{l}\text { Machinery, except } \\
\text { electrical }\end{array}$ & 1.0 & 18.2 & 14.7 & 45.5 \\
\hline $\begin{array}{l}\text { Electrical machinery } \\
\text { apparatus }\end{array}$ & 1.3 & 7.7 & 15.2 & 46.2 \\
\hline Transport equipment & 1.8 & & 21.1 & \\
\hline Scientific equipment & & 5.1 & 66.7 & 43.6 \\
\hline $\begin{array}{l}\text { Other manufacturing } \\
\text { industries }\end{array}$ & 11.1 & 7.1 & 33.3 & 40.5 \\
\hline Total & 3.0 & 15.7 & 20.3 & 56.6 \\
\hline
\end{tabular}

Source: Authors' calculations based on CMI Punjab 2000/01 (trimmed data).

According to the Enterprise Survey 2006/07 data for all Pakistan, exporters display a considerably higher capital-labor ratio in textiles, leather goods, other chemicals, electrical machinery, and other manufacturing; a somewhat higher ratio in garments; but significantly lower capital intensity in food manufacturing (Figure 6b). 
Figure 6b: Capital-labor ratio, by sector and exporting status, Enterprise Survey 2006/07

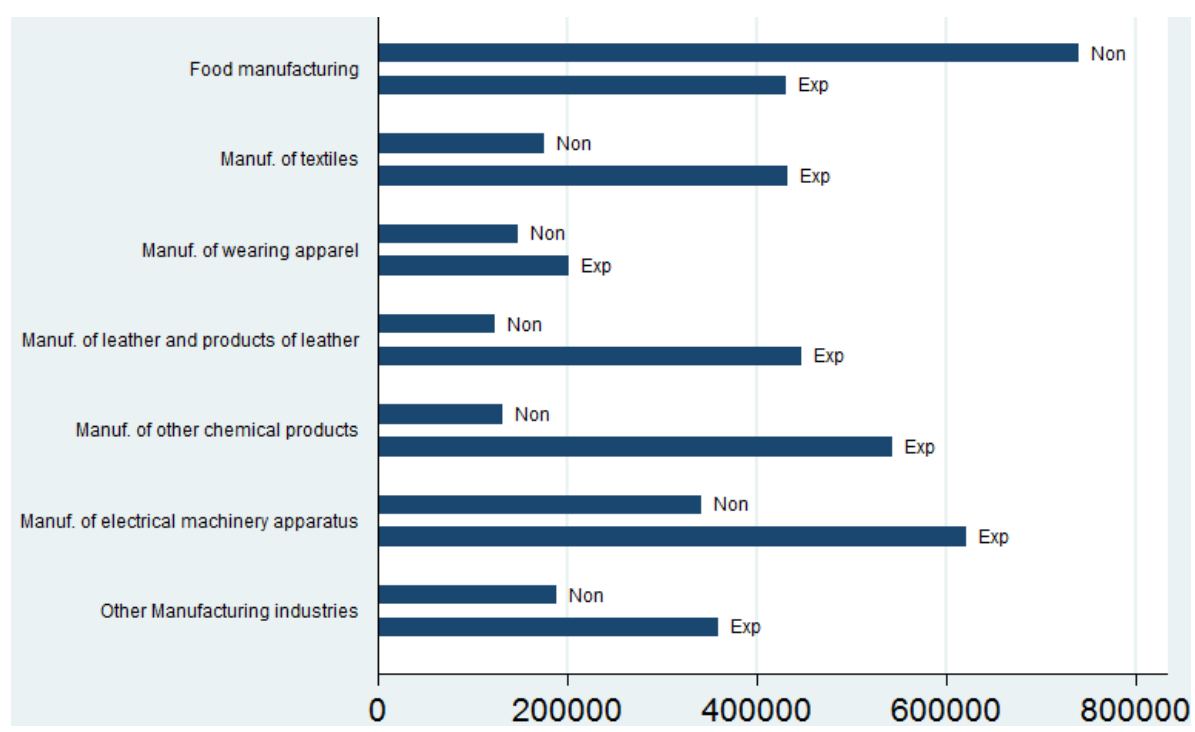

Source: Authors' calculations based on World Bank Enterprise Survey 2006/07.

\section{Other Differences Between Exporters and Nonexporters}

In this section, we note some additional dimensions along which exporting and nonexporting firms differ, including the use of imported inputs and the number of days the factory operates.

\subsection{Use of Imported Inputs}

In many industries, firms that export appear to also use a larger share of imported materials in their input mix, on average, compared to nonexporting firms (Figure 7 and Figure A5 in Annex 4). Sectors for which this difference is large include food manufacturing, paper products, printing/publishing, other chemicals, iron and steel, electrical machinery, pottery, transport equipment, fabricated metal products, and plastic products. The only sectors in which nonexporters exceed exporters by a large margin in their use of imported inputs are the relatively small scientific equipment and other manufacturing sectors. 
Figure 7: Use of imported inputs, by sector and exporting status, CMI Punjab 2000/01

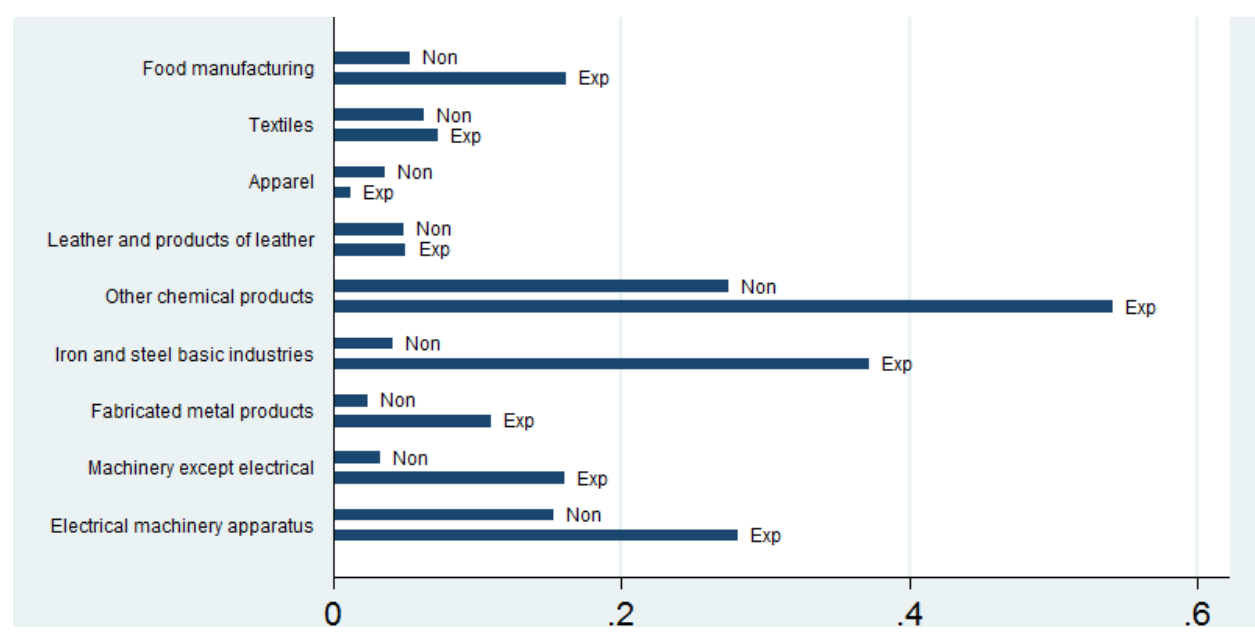

Source: Authors' calculations based on CMI Punjab 2000/01 (trimmed data).

\subsection{Number of Days a Factory is in Operation}

From the quantile plot in Figure 8, it would appear that exporters' factories operate, on average, more days than those of nonexporters. Only a small fraction of nonexporters reported being in operation more than 300 days in the year, whereas around a quarter of exporters reported operating 350 days in a year. One possible theory is that exporters are less subject to fluctuations in demand for their output and, therefore, shut down very infrequently.

Figure 8: Number of days the factory is operational, by exporting status

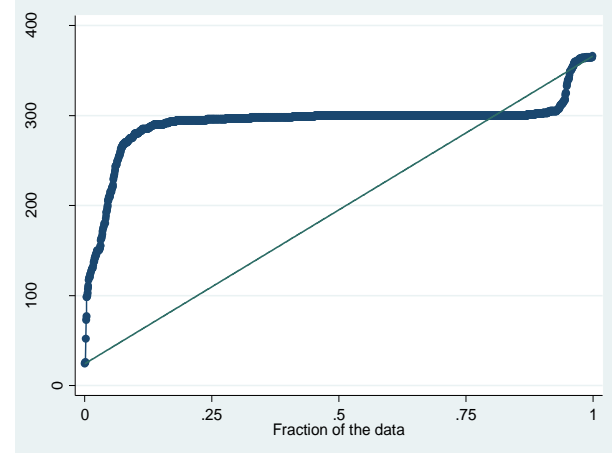

Panel A: Nonexporters

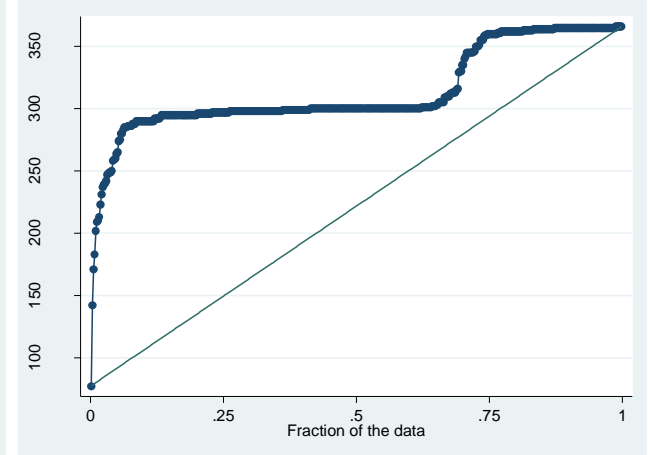

Panel B: Exporters

Source: Authors' calculations based on CMI Punjab 2000/01 (untrimmed data). 
However, when we look by sector at the share of exporters and nonexporters that operate longer than the sector average, there is no clear pattern differentiating the two groups (Table 7). The result appears to be driven mainly by textile producers, such that nearly 80 percent of exporting textile concerns operate more days than the industry average, whereas the same is true for only 16.5 percent of nonexporting textile producers. It is also the case that a larger share of exporters operate more days than the industry average (but to a smaller degree) in six other sectors: printing, industrial chemicals, plastic products, fabricated metal products, scientific equipment, and other manufacturing. For nine industries, the inequality is reversed; for the remaining three, the figures are nearly the same.

Table 7: Percentage of factories that operated longer than the industry average (in days), by sector and exporting status

\begin{tabular}{lcc}
\hline Sector & Exporters & Nonexporters \\
\hline Food manufacturing & 60.0 & 81.5 \\
Textiles & 79.6 & 16.5 \\
Apparel & 58.6 & 67.6 \\
Leather and products of leather & 64.7 & 73.9 \\
Paper and paper products & 75.0 & 74.4 \\
Printing, publishing, and allied industries & 100.0 & 64.5 \\
Industrial chemicals & 33.3 & 23.1 \\
Other chemical products & 44.4 & 82.3 \\
Rubber products & 50.0 & 89.5 \\
Plastic products & 100.0 & 76.9 \\
Pottery, china, and earthenware & 0.0 & 72.0 \\
Other nonmetallic mineral products & 100.0 & 76.7 \\
Iron and steel basic industries & 50.0 & 77.8 \\
Fabricated metal products & 100.0 & 85.6 \\
Machinery, except electrical & 63.6 & 71.8 \\
Electrical machinery apparatus & 76.9 & 74.7 \\
Transport equipment & & 49.1 \\
Scientific equipment & 51.3 & 33.3 \\
Other manufacturing industries & 61.9 & 55.6 \\
Total & 67.6 & 62.4 \\
\hline
\end{tabular}

Source: Authors' calculations based on CMI 2000/01 (trimmed data).

\section{Conclusions}

In terms of thinking about which sectors could improve living standards for workers and expand employment opportunities, the higher compensation and productivity of the export sectors and larger firm size 
are attractive features. When combined with the foreign exchange that accompanies exports, it seems that promoting the export-intensive sectors is a no-brainer. However, exporters tend to use more imported inputs and more capital per worker, some of which must also be imported and all of which must be financed. Given the credit constraints that firms frequently encounter and the shortages of foreign exchange to which the country is sometimes subject, one has to look more closely at the individual sectors.

The textiles industry is already the largest sector in terms of both manufacturing and exports: 23 percent of textile firms in the CMI Punjab 2000/01 export, and those that do, export more than half their output on average. Textile exporters tend to be considerably larger than nonexporters, compensate their workers somewhat better, and use modest quantities of imported inputs (due mainly to government restrictions on fabric importation). They are, however, very capital-intensive, purchasing both imported and local machinery.

In food manufacturing, only around 5 percent of firms export (CMI Punjab 2000/01) and those that do, export more than a third of their output. Exporters of food products are twice as large as nonexporters and pay their workers twice as much. They also use twice the imported inputs and have (surprisingly) among the highest capital-labor ratios of the industries studied, although firms seem to be more likely to buy locally manufactured rather than imported machinery.

According to the CMI Punjab 2000/01, the export participation of firms in the "other chemicals" sector is lower (9 percent), and less than 20 percent of sales (on average) comprise exports. Firms in this sector have a modest capital-labor ratio and commonly purchase locally built capital. Firms are not large, but their compensation is above average. The largest strike against the sector, however, is that it relies heavily on imported inputs.

Firms in the fabricated metal products sector do not use an excessive amount of imported inputs or capital per worker, but they are small and while exporters' employees are paid somewhat more, compensation in this sector is below average compared to exporters in other sectors. Firms in the nonelectrical machinery sector are similar except that the compensation paid to production workers is somewhat better. The sector imports more capital, however, than most other sectors. The iron and steel and electrical machinery apparatus sectors are average according to most measures, except that they use imported materials somewhat more intensively. 
More than half the apparel producers surveyed in the CMI Punjab 2000/01 were exporting, and export nearly all their output (93 percent). The capital-labor ratio and use of imported inputs is modest for both exporters and nonexporters; fewer than 5 percent of exporters imported capital in 2000/01. Exporters are around eight times the size of nonexporters, employ on average 400 workers, and offer significantly higher compensation. The picture that emerges from the Enterprise Survey is not as favorable, but still positive. Therefore, the government's recent emphasis on developing the readymade garments sector is well placed.

The CMI Punjab 2000/01 captures only a small number of leather products firms (this coverage is better in the World Bank dataset), but nearly half the firms export, selling most of their output abroad. These firms use very few imported inputs. Exporters have a higher (although still relatively modest) capital-labor ratio; in most cases, they purchase locally produced machinery. Total employment is larger among exporters, but their firm size is not very large compared to other sectors. Compensation is, however, above average compared to other sectors in the CMI Punjab, especially among exporters of leather; this same picture does not emerge from the World Bank Enterprise Survey data. This may be another sector whose potential is worth exploring more closely. 


\section{References}

Aw, B. Y., Chung, S., \& Roberts, M. J. (2000). Productivity and turnover in the export market: Micro-level evidence from the Republic of Korea and Taiwan (China). World Bank Economic Review, 14(1), 65-90.

Aw, B. Y., Roberts, M., \& Xu, D. Y. (2011). R\&D investment, exporting, and productivity dynamics. American Economic Review, 101(4), 13121344.

Bernard, A., B. \& Jenson, J. B. (2004). Exporting and productivity in the USA. Oxford Review of Economic Policy, 20(3), 343-357.

Bernard, A. B., Jensen, J. B., Redding, S. J., \& Schott, P. K. (2007). Firms in international trade. Journal of Economic Perspectives, 21(3), 105-130.

Bernard, A. B., Jensen, J. B., Redding, S. J., \& Schott, P. K. (2011). The empirics of firm heterogeneity and international trade (Working Paper No. 17627). Cambridge, MA: National Bureau of Economic Research.

Chen, M., Otsuki, T., \& Wilson, J. (2006). Do standards matter for export success? (Policy Research Working Paper No. 3809). Washington, DC: The World Bank.

De Loecker, J. (2007). Do exports generate higher productivity? Evidence from Slovakia. Journal of International Economics, 73(1), 69-98.

Easterly, W., Reshef, A., \& Schwenkenberg, J. (2009). The power of exports (Policy Research Working Paper No. 5081). Washington, DC: The World Bank.

Gervais, A. (2012). Product quality and firm heterogeneity in international trade (Mimeo). Notre Dame, IN: University of Notre Dame, Department of Economics.

Hsieh, C.-T., \& Klenow. (2009). Misallocation and manufacturing TFP in China and India. Quarterly Journal of Economics, 124(4), 1403-1448.

Khan, I. U., \& Kalirajan, K. (2011). The impact of trade costs on exports: An empirical modeling (Working Paper No. 2011/07). Canberra: Australia South Asia Research Centre. 
Melitz, M. J. (2003). The impact of trade on intra-industry reallocations and aggregate industry productivity. Econometrica, 71(6), 1695-1725.

Mukim, M. (2011). Does exporting increase productivity? Evidence from India (Mimeo). London: London School of Economics and Political Science. $\quad$ Retrieved from http:/ / personal.lse.ac.uk/mukim/mukim_jmp.pdf

Roberts, M. J., \& Tybout, J. R. (1997). The decision to export in Colombia: An empirical model of entry with sunk costs. American Economic Review, 87(4), 545-564.

Van Biesebroeck, J. (2006). Exporting raises productivity in sub-Saharan African manufacturing plants. Journal of International Economics, 67(2), 373-391.

World Bank. (2014). Enterprise Surveys | Data [Database]. Available from http:/ / data.worldbank.org/ data-catalog/enterprise-surveys

Zia, B. (2008). Export incentives, financial constraints, and the (mis)allocation of credit: Micro-level evidence from subsidized export loans. Journal of Financial Economics, 87(2), 498-527. 


\section{Annex 1}

\section{Table A1: Commodities' share of total exports of Pakistan}

\begin{tabular}{lcc}
\hline Commodity & $\mathbf{2 0 0 0 / 0 1}$ & $\mathbf{2 0 0 9 / 1 0}$ \\
\hline 1. Fish and fish preparations & 0.01 & 0.01 \\
2. Rice & 0.06 & 0.11 \\
3. Molasses & 0.00 & 0.00 \\
4. Raw wool & 0.00 & 0.00 \\
5. Raw cotton & 0.01 & 0.01 \\
6. Cotton waste & 0.00 & 0.00 \\
7. Leather & 0.03 & 0.02 \\
8. Cotton yarn & 0.12 & 0.07 \\
9. Cotton thread & 0.00 & 0.00 \\
10. Cotton cloth & 0.11 & 0.09 \\
11. Petroleum and petroleum products & 0.02 & 0.05 \\
12. Synthetic textiles & 0.06 & 0.02 \\
13. Footwear & 0.00 & 0.00 \\
14. Animal casings & 0.00 & 0.00 \\
15. Vegetables and fruits & 0.01 & 0.02 \\
16. Guar and products & 0.00 & 0.00 \\
17. Towels of cotton & 0.03 & 0.03 \\
18. Paints and varnishes & 0.00 & 0.00 \\
19. Tobacco, raw and manufactured & 0.00 & 0.00 \\
20. Readymade garments and hosiery & 0.19 & 0.16 \\
21. Drugs and chemicals & 0.01 & 0.04 \\
22. Surgical instruments & 0.01 & 0.01 \\
23. Carpets and rugs & 0.03 & 0.01 \\
24. Sporting goods & 0.03 & 0.02 \\
25. Others & 0.25 & 0.31 \\
\hline
\end{tabular}

Source: http://www.pbs.gov.pk/content/pakistan-statistical-year-book-2011. Calculated from table 9.7 (major exports by commodity), Pakistan Statistical Yearbook 2011. 
Table A2: Exporter status by disaggregated industry code

\begin{tabular}{|c|c|c|c|}
\hline PSIC & & No. of firms & \% Exporters \\
\hline 1121 & Dairy products (except ice cream) & 8 & 12.5 \\
\hline 1122 & Ice cream & 2 & 0.0 \\
\hline 1130 & Processing and preserving of fruits and vegetables & 3 & 0.0 \\
\hline 1151 & Hydrogenated vegetable oils & 24 & 4.2 \\
\hline 1152 & Vegetable oils (except hydro CS oils) & 1 & 0.0 \\
\hline 1153 & Cottonseed oils & 28 & 10.7 \\
\hline 1159 & Vegetable and inedible animal oils and fats & 1 & 0.0 \\
\hline 1161 & Rice milling & 15 & 40.0 \\
\hline 1162 & Wheat and grain milling (except rice) & 176 & 0.0 \\
\hline 1163 & Preparation of grain-milled products & 4 & 0.0 \\
\hline 1169 & Wheat and grain milling and products n.e.c. & 1 & 100.0 \\
\hline 1171 & Breads, buns, bakery products, except biscuits & 11 & 0.0 \\
\hline 1172 & Biscuits & 10 & 0.0 \\
\hline 1179 & Other bakery products n.e.c. & 4 & 25.0 \\
\hline 1181 & Refined sugar & 29 & 6.9 \\
\hline 1191 & Cocoa, chocolate, and confectionery & 5 & 20.0 \\
\hline 1199 & Confectionery n.e.c. & 1 & 0.0 \\
\hline 1212 & Blending of tea & 1 & 0.0 \\
\hline 1222 & Feed for fowls & 16 & 0.0 \\
\hline 1291 & Starch and its products & 2 & 50.0 \\
\hline 1292 & Edible salt refining & 1 & 0.0 \\
\hline 1293 & Ice & 12 & 0.0 \\
\hline 1299 & Misc food products n.e.c. & 3 & 33.3 \\
\hline 1320 & Wine & 1 & 0.0 \\
\hline 1341 & Fruit drinks & 5 & 20.0 \\
\hline 1349 & Soft drinks and carbonated water n.e.c. & 11 & 9.1 \\
\hline 1410 & Cigarettes (including pipe tobacco) & 3 & 0.0 \\
\hline 2011 & Spinning of cotton & 152 & 63.8 \\
\hline 2012 & Weaving and finishing of cotton textiles & 45 & 64.4 \\
\hline 2020 & Spinning, weaving, and finishing of woolen textiles & 34 & 8.8 \\
\hline 2030 & Spinning, weaving, and finishing of jute textiles & 6 & 50.0 \\
\hline 2040 & Spinning, weaving, and finishing of silk textiles & 32 & 15.6 \\
\hline 2050 & Spinning, weaving, and finishing of narr. fabrics & 7 & 0.0 \\
\hline 2070 & Dyeing, bleaching, and finishing of textiles & 205 & 8.8 \\
\hline 2120 & Made-up textiles, apparel goods except wearing & 21 & 38.1 \\
\hline 2130 & Knitting mills & 79 & 48.1 \\
\hline 2141 & Carpets and rugs (cotton) & 1 & 0.0 \\
\hline 2142 & Carpets and rugs (wool) & 5 & 40.0 \\
\hline 2150 & Cordage, rope, and twine & 2 & 0.0 \\
\hline 2160 & Spooling and thread ball making & 2 & 0.0 \\
\hline
\end{tabular}




\begin{tabular}{|c|c|c|c|}
\hline PSIC & & No. of firms & \% Exporters \\
\hline 2190 & Textiles n.e.c. & 10 & 10.0 \\
\hline 2210 & Readymade garments & 50 & 86.0 \\
\hline 2290 & Wearing apparel n.e.c. (except footwear) & 3 & 66.7 \\
\hline 2310 & Tanning and leather finishing & 41 & 41.5 \\
\hline 2332 & Suitcases & 1 & 100.0 \\
\hline 2339 & Products of leather and leather substitutes & 6 & 66.7 \\
\hline 2410 & Leather footwear & 9 & 44.4 \\
\hline 2510 & Cotton ginning and pressing & 221 & 1.8 \\
\hline 3120 & Plywood and plywood products & 6 & 0.0 \\
\hline 3140 & Hardboard and its products & 11 & 0.0 \\
\hline 3190 & Wood and cork products n.e.c. (except furniture) & 1 & 0.0 \\
\hline 3210 & Wooden furniture & 12 & 0.0 \\
\hline 3220 & Fixtures & 1 & 100.0 \\
\hline 4110 & Pulp and paper & 15 & 13.3 \\
\hline 4120 & Paperboard & 6 & 16.7 \\
\hline 4130 & Articles of pulp, paper, and paperboard & 15 & 6.7 \\
\hline 4190 & Paper and paper products n.e.c. & 12 & 8.3 \\
\hline 4220 & Printing and publishing of books, periodicals & 6 & 0.0 \\
\hline 4230 & Commercial lithographing and job printing & 22 & 0.0 \\
\hline 4240 & Printed cards and stationery & 3 & 33.3 \\
\hline 4260 & Metal sheet printing & 1 & 0.0 \\
\hline 4290 & Printing, publishing, and allied industry n.e.c & 1 & 0.0 \\
\hline 5010 & Medical and pharmaceutical preparations & 61 & 11.5 \\
\hline 5020 & Unani medicines & 9 & 11.1 \\
\hline 5040 & Homeopathic and biochemical medicines & 2 & 0.0 \\
\hline 5111 & Alkalis & 6 & 16.7 \\
\hline 5112 & Acids (except sulfur) salts (excl. common salt) & 8 & 12.5 \\
\hline 5113 & Sulfuric acid & 4 & 25.0 \\
\hline 5120 & Dyes, colors, and pigments & 3 & 0.0 \\
\hline 5130 & Compressed liquefied and solidified gases & 8 & 0.0 \\
\hline 5140 & Fertilizers & 5 & 0.0 \\
\hline 5150 & Insecticides and pesticides & 3 & 0.0 \\
\hline 5160 & Synthetic resins, plastic materials & 6 & 0.0 \\
\hline 5210 & Paints, varnishes, and lacquers & 11 & 0.0 \\
\hline 5220 & Perfumes and cosmetics & 3 & 33.3 \\
\hline 5230 & Soap (all kinds) and detergents & 23 & 0.0 \\
\hline 5250 & Matches & 2 & 0.0 \\
\hline 5260 & Ink (all kinds) & 3 & 33.3 \\
\hline 5290 & Chemical products n.e.c. & 7 & 14.3 \\
\hline 5410 & Petroleum products & 2 & 0.0 \\
\hline 5420 & Coal products and by-products & 1 & 0.0 \\
\hline 5510 & Tyres and tubes & 4 & 0.0 \\
\hline
\end{tabular}




\begin{tabular}{|c|c|c|c|}
\hline PSIC & & No. of firms & \% Exporters \\
\hline 5520 & Rebuilding and retreading tyres and tubes & 1 & 0.0 \\
\hline 5591 & Rubber footwear & 4 & 25.0 \\
\hline 5592 & Vulcanized rubber products & 2 & 50.0 \\
\hline 5593 & Rubber belting & 4 & 0.0 \\
\hline 5599 & Misc rubber products n.e.c. & 8 & 0.0 \\
\hline 5610 & Plastic footwear & 6 & 0.0 \\
\hline 5690 & Misc plastic products n.e.c & 22 & 4.5 \\
\hline 6110 & Earthenware & 1 & 0.0 \\
\hline 6120 & China and ceramics & 22 & 9.1 \\
\hline 6190 & Pottery, china, and earthenware n.e.c. & 4 & 0.0 \\
\hline 6210 & Glass & 3 & 33.3 \\
\hline 6220 & Glass products & 5 & 20.0 \\
\hline 6910 & Bricks, tiles, and clay products & 10 & 10.0 \\
\hline 6920 & Cement & 6 & 0.0 \\
\hline 6930 & Cement products & 8 & 0.0 \\
\hline 6940 & Lime, plaster and their products & 2 & 0.0 \\
\hline 6950 & Refractories & 1 & 0.0 \\
\hline 6990 & Nonmetallic mineral products n.e.c. & 6 & 0.0 \\
\hline 7110 & Iron and steel mills & 15 & 0.0 \\
\hline 7120 & Iron and steel foundries & 14 & 0.0 \\
\hline 7130 & Iron and steel rerolling mills & 73 & 2.7 \\
\hline 7190 & Iron and steel basic industries n.e.c. & 1 & 0.0 \\
\hline 7210 & Basic aluminum and aluminum alloys & 4 & 0.0 \\
\hline 7220 & Basic copper and copper alloys & 6 & 0.0 \\
\hline 8010 & Cutlery & 11 & 63.6 \\
\hline 8020 & Hand and edge tools & 2 & 0.0 \\
\hline 8030 & Razors, safety razors, and razor blades & 1 & 100.0 \\
\hline 8040 & Furniture and fixtures, primarily of metal & 7 & 0.0 \\
\hline 8050 & Structural metal products & 4 & 25.0 \\
\hline 8060 & Metal stamping, coating, and electroplating & 3 & 0.0 \\
\hline 8070 & Heating, cooking, and lighting equipment & 6 & 0.0 \\
\hline 8080 & Wire products & 3 & 0.0 \\
\hline 8090 & Utensils, aluminum & 27 & 3.7 \\
\hline 8120 & Utensils, steel & 2 & 0.0 \\
\hline 8130 & Metal barrels and drums & 3 & 33.3 \\
\hline 8140 & Tin cans and tin-ware & 5 & 0.0 \\
\hline 8150 & Metal trunks & 1 & 0.0 \\
\hline 8160 & Bolts, nuts, rivets, and washers & 4 & 0.0 \\
\hline 8170 & Plumbing equipment & 25 & 4.0 \\
\hline 8180 & Safes and vaults & 2 & 0.0 \\
\hline 8190 & Fabricated metal products n.e.c. & 21 & 4.8 \\
\hline 8210 & Engines and turbines & 7 & 0.0 \\
\hline
\end{tabular}




\begin{tabular}{llrr}
\hline PSIC & & No. of firms & \% Exporters \\
\hline 8220 & Agricultural machinery and equipment & 64 & 7.8 \\
8230 & Metal- and wood-working machinery & 5 & 20.0 \\
8240 & Textile machinery & 15 & 13.3 \\
8250 & Industrial, except agricultural, metal textile & 16 & 0.0 \\
& machinery & & \\
8270 & Sewing machines & 6 & 0.0 \\
8290 & Machinery equipment n.e.c. (except electrical) & 19 & 26.3 \\
8310 & Electrical industrial machinery and apparatus & 15 & 13.3 \\
8321 & Radio, TV receiving and transmitting equipment & 1 & 0.0 \\
8322 & Gramophones, dictating machines, tape recorders & 1 & 0.0 \\
8323 & Telephone and telegraph equipments & 1 & 100.0 \\
8331 & Electric fans & 38 & 15.8 \\
8332 & Electrical appliances (except fans) & 25 & 8.0 \\
8340 & Insulated wires and cables & 7 & 14.3 \\
8350 & Electric bulbs and tubes & 4 & 0.0 \\
8360 & Batteries & 2 & 0.0 \\
8390 & Electrical apparatus and supplies n.e.c. & 8 & 25.0 \\
8441 & Motor vehicles & 1 & 0.0 \\
8442 & Automobile parts & 38 & 5.3 \\
8450 & Motorcycles, auto-rickshaws & 4 & 0.0 \\
8461 & Complete cycles & 3 & 0.0 \\
8462 & Cycle parts & 8 & 0.0 \\
8491 & Body building & 3 & 0.0 \\
8492 & Repair of vehicles & 12 & 0.0 \\
8510 & Surgical medical and dental instruments & 47 & 93.6 \\
8520 & Watches and clocks & 1 & 100.0 \\
9200 & Sporting and athletic goods & 38 & 94.7 \\
9330 & Musical instruments & 2 & 100.0 \\
9370 & Pens and other office articles & 4 & 25.0 \\
9390 & Buttons, studs, hooks, and fasteners & 7 & 0.0 \\
9420 & Bone crushing & 6 & 85.7 \\
9490 & Other manufacturing industries n.e.c. & 33.3 \\
\hline & & &
\end{tabular}

Source: CMI 2000/01. 
Annex 2

\section{Measurement of TFP}

Estimates of and the distributions of TFPR and TFPQ are based on calculations of the following four productivity measures (Hsieh \& Klenow, 2009):

$$
\begin{aligned}
& T F P R_{s i}=P * A_{s i}=\frac{P_{s i} Y_{s i}}{K_{s i}^{\alpha_{s}} L_{s i}^{1-\alpha_{s}}} \\
& T F P Q_{s i}=A_{s i}=\kappa_{s} \frac{\left(P_{s i} Y_{s i}\right)^{\frac{\sigma}{\sigma-1}}}{K_{s i}^{\alpha_{s}} L_{s i}^{1-\alpha_{s}}}
\end{aligned}
$$

Where $\kappa_{S}=\frac{\left(P_{S} Y_{S}\right)^{-\frac{1}{\sigma-1}}}{P_{S}}$

$$
\overline{T F P R_{s}}=\frac{\sigma}{\sigma-1}\left(\overline{\frac{M R P K_{s}}{\alpha_{s}}}\right)^{\alpha_{s}}\left(\overline{\frac{M R P L_{s}}{1-\alpha_{s}}}\right)^{1-\alpha_{s}}
$$

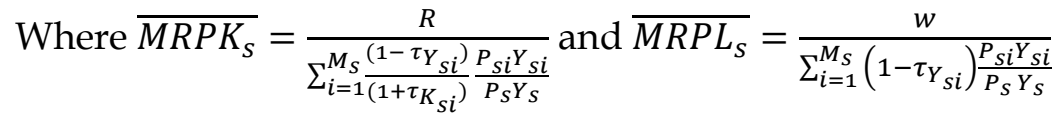

$$
A_{s}=\left[\sum_{i=1}^{M_{s}}\left(A_{s i} \frac{\overline{T F P R_{s}}}{T F P R_{s i}}\right)^{\sigma-1}\right]^{\frac{1}{\sigma-1}}
$$

The first expression (A1) measures the plant-level Total Factor Revenue Productivity. Expression (A2) measures the plant-level $T F P Q$ with nominal output $P_{s i} Y_{s i}$. In the data sets, plant-level real output is unobserved. Therefore, observed nominal output is raised to the power $\frac{\sigma}{\sigma-1}$ to impute the real output $Y_{s i}$. This exercise makes use of a scalar $\kappa_{s}$, which is unobserved and therefore assumed as $\kappa_{s}=1$. This assumption will not affect are calculations for relative productivities. Expression (A3) is a measure of industry-level Total Factor Revenue Productivity. This expression is derived by taking a geometric mean of industry-level $\overline{M R P K}$ and $\overline{M R P L}$. Finally the last productivity measure (A4) is an industry-level $T F P Q$. 
In order to compute the $\overline{M R P K}$ and $\overline{M R P L}$ we need information on plant level distortions. Hsieh and Klenow (2009) impute the distortion parameters in the following manner:

$$
\begin{aligned}
\tau_{K_{s i}} & =\frac{\alpha_{s}}{\left(1-\alpha_{s}\right)} \frac{w L_{s i}}{R K_{s i}}-1 \\
\tau_{Y_{s i}} & =\frac{\sigma}{(\sigma-1)} \frac{w L_{s i}}{\left(1-\alpha_{s}\right) P_{s i} Y_{s i}}-1
\end{aligned}
$$

Expression (A5) implies that a capital distortion is observed where the ratio of the plant's wage bill to capital stock is higher than the ratio of their respective output elasticities. The next expression (A6) implies that an output distortion is observed where the labor share is lower than the elasticity of output with respect to labor. In both cases, we are comparing undistorted US labor and capital shares with the corresponding information observed for Punjab to infer the distortions.

This exercise requires following key parameters: labor and capital shares $\left(\alpha_{s}\right)$, elasticity of substitution between plants $(\sigma)$, rental price of capital $(R)$, and industry output shares $\left(\theta_{s}\right)$. We will follow the same conventions in order to maintain the comparability of our results to Hsieh and Klenow's analysis. We have already discussed source of labor and capital distortions. Elasticity of substitution between plants is positively correlated with liberalization gains; therefore, to avoid the exaggeration of results, it is taken as the modest estimate of $\sigma=3$. Undistorted rental price of capital is taken as $R=0.10$. For each firm, this parameter will change according to observed capital distortion. Furthermore, since we are using relative productivity measures, choice of this parameter will not affect our liberalization experiments. Finally, industry output shares are taken as ratio of aggregate industry value added to aggregate economywide value added $\theta_{S}=\frac{P_{S} Y_{S}}{Y}$ 


\section{Annex 3}

\section{Caveats About the Data}

Coverage in the CMI may be somewhat smaller than implied by the summary reports. According to the Pakistan Bureau of Statistics' summary report on the CMI 2000/01, 68.8 percent of still-operating firms responded in the Punjab. According to the 2002 Directory of Industries, there were 287 surgical instrument producers with at least ten employees, but the 2000/01 CMI captures only 47 firms in this sector. Furthermore, there appear to be variations by industry: the 2002 Directory of Industries reports 43 sporting goods firms with at least ten employees, while the 2000/01 CMI dataset indicates 38 firms in the same industry. Moreover, 267 firms do not report any sales (local or export) of final goods and earn their income mainly as subcontractors to other firms. 
Annex 4

\section{Figures for Other Sectors Considered} 2000/01.

All the figures in this annex are based on data from the CMI Punjab

Figure A1: Average labor productivity, by sector and exporting status

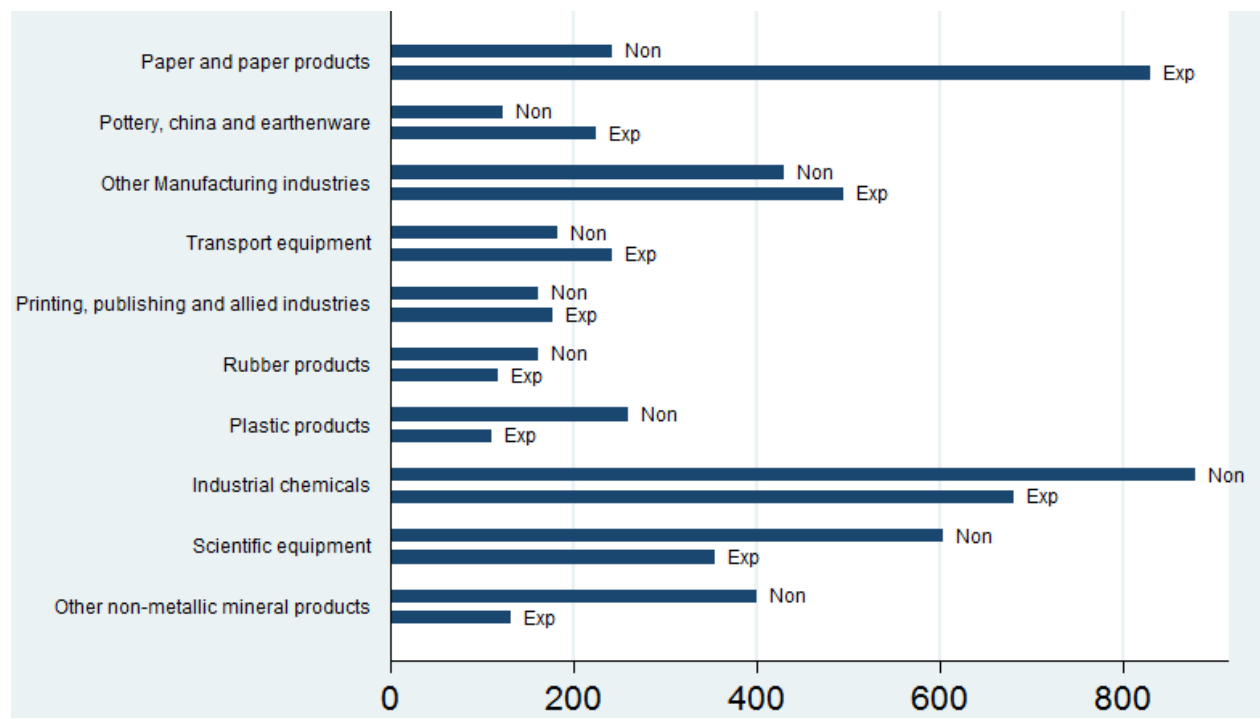

Figure A2: Average employment, by sector and exporting status

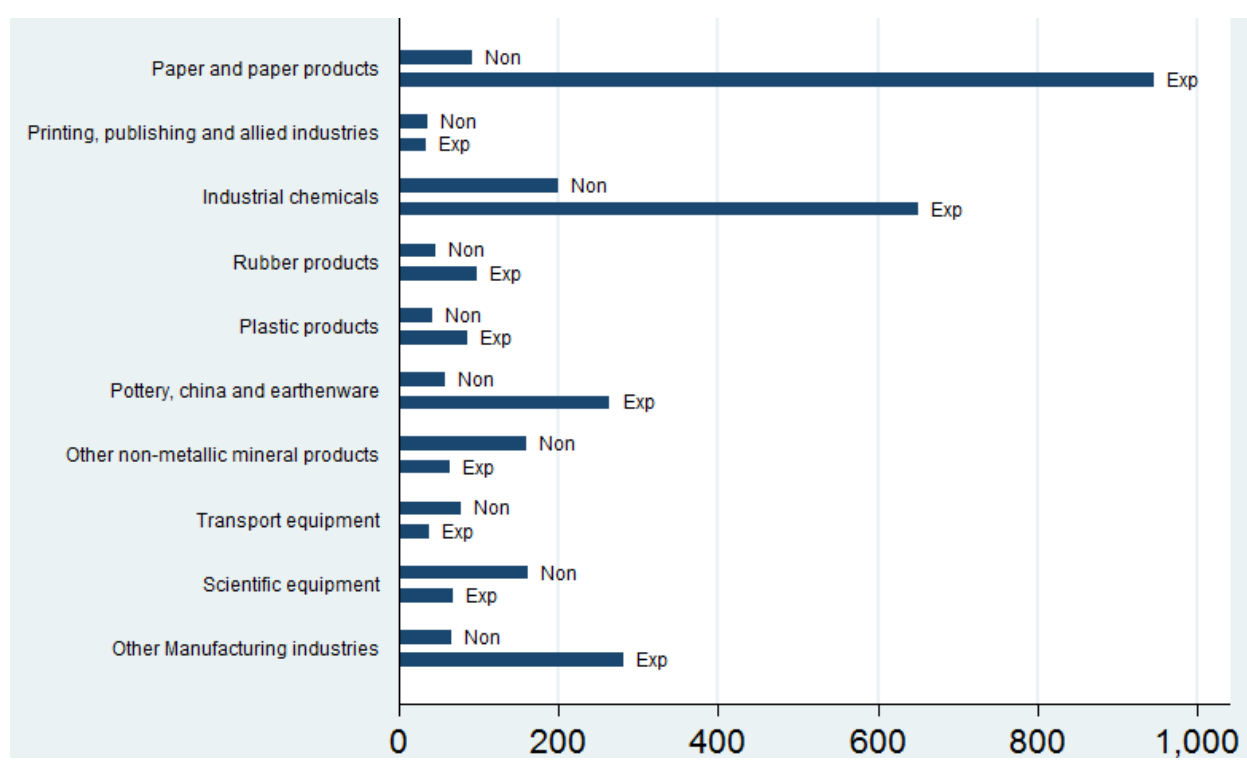


Figure A3: Average compensation for production (including contract) workers, by sector and exporting status

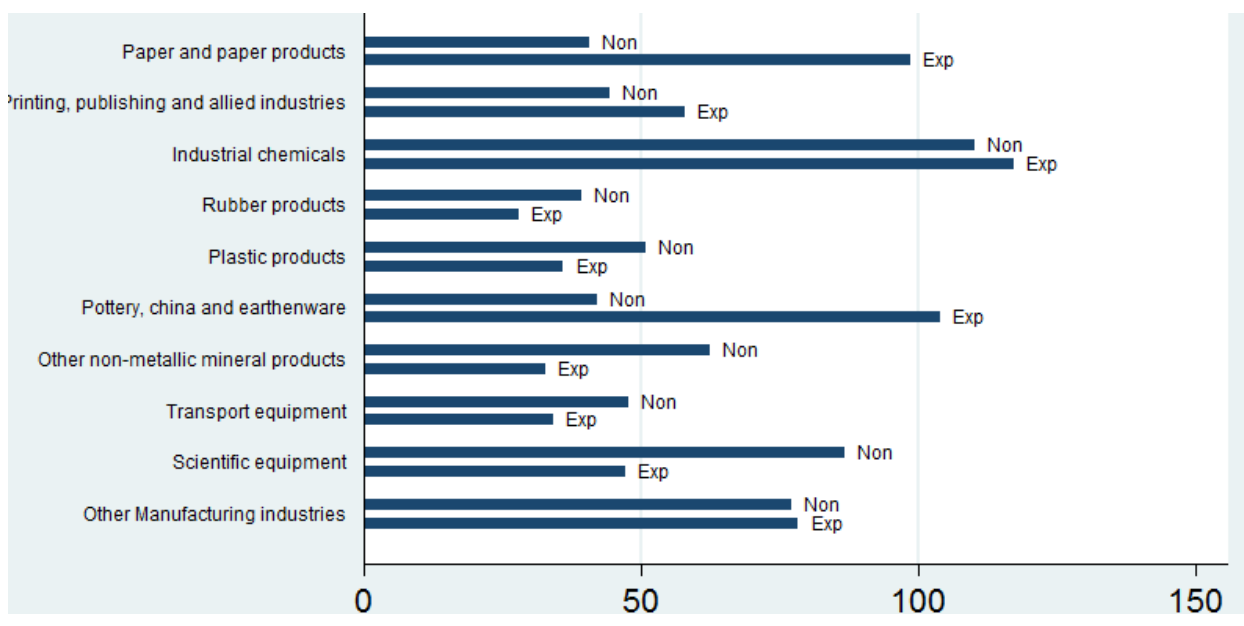

Figure A4: Capital-labor ratio, by sector and exporting status

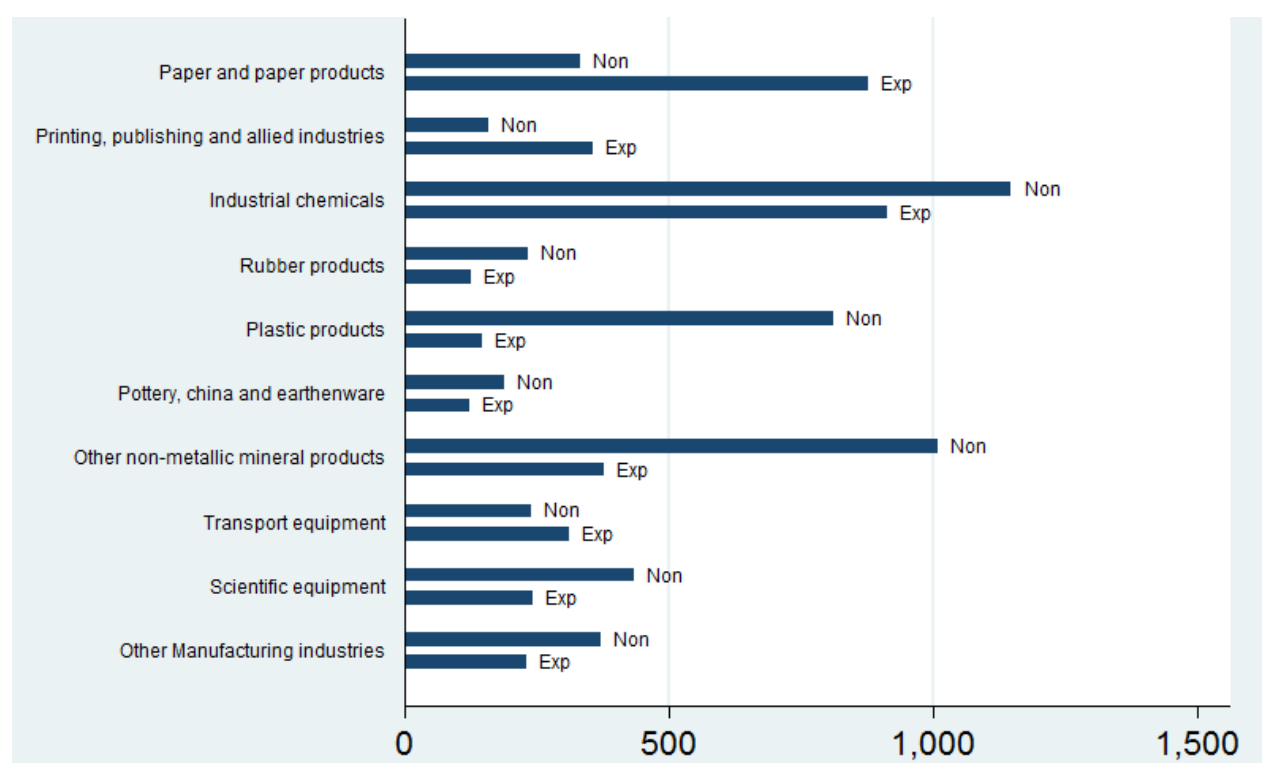


Figure A5: Use of imported inputs, by sector and exporting status

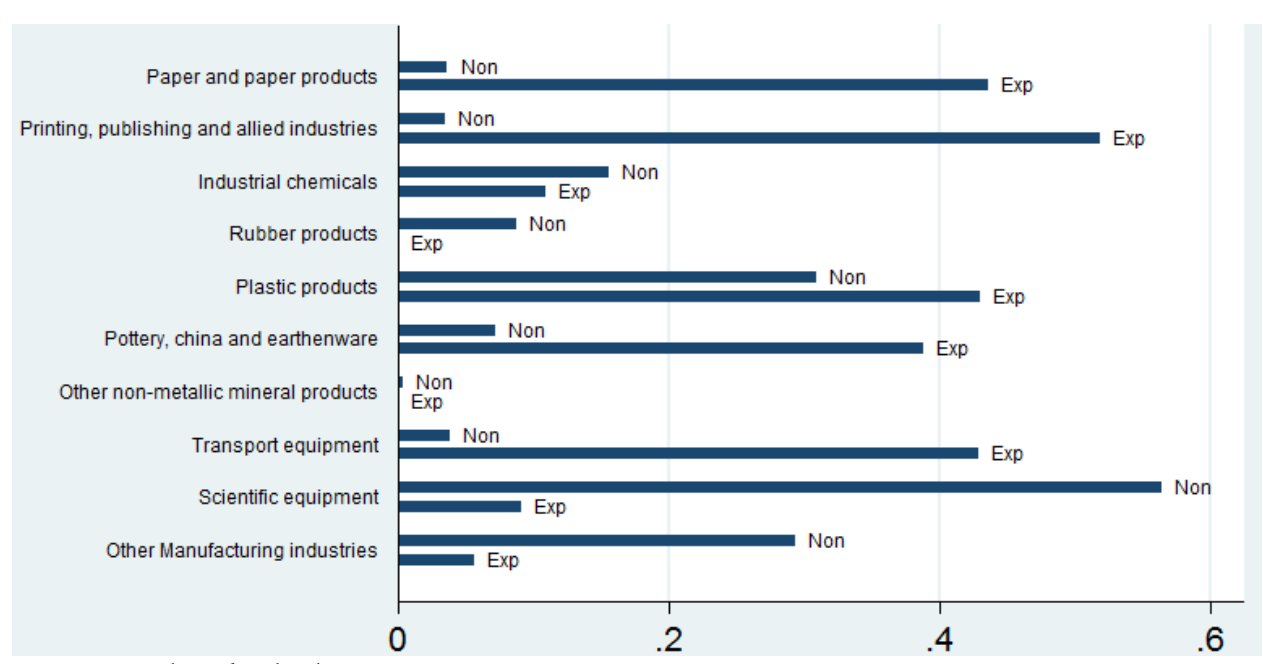

Source: Authors' calculations. 